\title{
THE F00D OF FISHES.
}

\section{BY S. A. FORBES.}

For a clear conception of the general and intricate interdependence of the different forms of organic life upon the earth, one cannot do better than to study thoroughly the life of a permanent body of fresh water-a river or smaller stream, or, better than these, a lake. The animals of such a body of water are, as a whole, curiously isolated - closely related among themselves in all their interests, but so far independent of the life of the land about them that if every terrestrial plant and animal were annihilated it would doubtless be long before the general multitude of the inhabitants of the lake or stream would feel the effects of this event in any very important way.

Further, the greater difficulty of communication between the different parts of a water system as compared with the different regions of the land, is such that the former are much the more sharply limited. There is very much less interchange of all kinds between two branches of the same stream, for example, than between the tracts of land which they separate. Consequently, one finds in a single body of water a far more complete and independent equilibrium of organic life and activity than in any equal body of land. It forms a little world within itselfa microcosm within which all the elemental forces are at work and the play of life goes on in full, but on so small a scale as to bring it easily within the mental grasp.

Nowhere can one see more clearly illustrated what may be called the sensibility of such an organic complex-expressed by the fact that whatever affects any species belonging to it, must speedily have its influence of some sort upon the whole assemblage. He will thus be made to see the impossibility of studying any form successfully out of relation to the other forms-the necessity for taking a comprehensive survey of the whole as a condition to a sat-. isfactory understanding of any part. If one wishes to be- 
come acquainted with the black bass, for example, he will learn but little if he limits himself to that species. $\mathrm{He}$ must evidently study also the species upon which it depends for its existence, and the various conditions upon which these depend. He must likewise study the species with which it comes in competition, and the entire system of conditions affecting their prosperity. Leaving out any of these, he is like one who undertakes to make out the construction of a watch, but overlooks one wheel; and by the time he has studied all these sufficiently, he will find that he has run through the whole complicated mechanism of the aquatic life of the locality, both animal and vegetable, of which his species forms but a single element.*

In such a general survey of the plants and animals of a region, the study of their food relations will be found to afford an admirable objective point. Doubtless, of all the features of the environment of an individual, none affect it at the same time so powerfully, so variously and so intimately as the elements of its food. Even climate, season, soil and the inorganic circumstances generally, influence an animal through its food quite as much as by their direct action. It is through the food relation that animals touch each other and the surrounding world at the greatest number of points, here they crowd upon each other the most closely, at this point the struggle for existence becomes sharpest and most deadly; and, finally, it is through the food relation almost entirely that animals are brought in contact with the material interests of man. Both for the student of science and for the economist, therefore, we find this subject of peculiar interest and value. It includes many of the most important relations

\footnotetext{
* I cannot too strongly emphasize the fact-frequently illustrated, I venture to hope, by the papers of this series-that a comprehensive survey of our entire natura! history is absolutely essential to a good working knowledge of those parts of it which chiefly attract popular attention, -that is, its edible fishes, its injurious and beneficial insects; and its parasitic plants. Such a survey, however, should not stop with a study of the dead forms of Nature, ending in mere lists and descriptions. To have an applicable value, it must treat the life of the region as an organic unit, must study it in action, and direct principal attention to the laws of its activity.
} 
of a species, and may properly be made the nucleus about which all the facts of its natural history are gathered.

In a paper on the food of Illinois fishes published in the second bulletin of this Laboratory, the subject was treated in a general and cursory way, the amount of material upon which that paper was based being insufficient for exact or detailed description. The favor with which that preliminary notice was received, has made it possible to undertake a more serious investigation; and this paper contains ail account of the food of the Acanthopteri of the State which I believe to be nearly or quite sufficient for the student of science and for the practical fish-culturist. It is still necessary only to study the food of specimens under a half-inch length, and to test the value of the general conclusions here reached, by occasional examinations of fishes taken from other waters at other seasons of the year. Among the results of this study, those relating to the food of the young are especially worthy of attention, and these have therefore been summed up separately.

The explanation of certain structural conditions about the mouth, throat and gills, has proceeded so far as to make it very likely that a number of definite general eorrespondences between structure and food will be made out, which will enable us to tell with considerable accuracy and detail what the food of an unknown fish must be, by a mere inspection of the fish itself; provided, of course, that we know what food is accessible to it in its habitat. It seems likely to prove to be a general rule that a fish makes scarcely more than a mechanical selection from the articles of food accessible to it, taking almost indifferently whatever edible things the water contains which its habitual range and its peculiar alimentary apparatus enable it to appropriate, and eating of these in about the ratio of their relative abundance and the ease with which they can be appropriated at any time and place. If this is so, knowing the structure of a fish and the contents of a body of water, we shall be able to tell, $a$ priori, what the fish will eat if placed therein.

This is, in fact, the objective point of the present investigation-to arrive at a knowledge of the correlations of 
structure and food habits sufficiently detailed and exact to make the tedious and difficult labor of examining the contents of stomachs unnecessary hereafter. Some generalizations of this sort are given in the following pages, and others relate to genera not included in this report.

The method of this paper differs from that of the previous one referred to by the calculation of the ratios of the different kinds of food for each species or group of individuals. These ratios were obtained by averaging careful estimates of the relative amounts of the different food elements found in each stomach.

It is proposed to follow a similar method hereafter down through the remaining orders of the class. Most of the material has been collected for this purpose, and much of it has been already studied.

\section{Order T E L E O C E P H A L .}

\section{Suborder ACANTHOPTERI.}

This suborder includes all Illinois fishes which have the anterior dorsal fin (where there are two) or the first rays of the dorsal (where there is but one) stiff, spinous, and sharp, and united by an evident membrane; excepting only the remarkable "brook silversides," which is placed by Drs. Gill and Jordan in another group. It embraces all our game fishes except those belonging to the pickerel family (Esocide) and the salmon family (Salmonida). Its principal members are the darters, the various species of perch and bass, the sunfishes, and the sheepshead. Forty-six species of the order have been collected in the State, but only thirty-four of these are common enough to form features of any importance in our fish fauna.

The most numerous family of the group is the Centrarchide (sunfishes); the most important species are the two kinds of black bass, the pike-perch or "wall-eyed pike," **

\footnotetext{
* It is generally to be desired that the absurd names of "Salmon" and "Jack Salmon" for these species should be, suppressed. They might as well be called suckers or catfishes or minnows, as far as accuracy is concerned. Common names are many times harder to kill than the cat of the proverb, however; and it is probable that unnumbered generations will confinue to call the pike-perch "salmon"; the sunfishes, "perch": and the black bass, "trout."
} 
the common perch, the white bass, and the croppie or silver bass.

The following account of the food of this suborder is based upon the careful microscopic study of the contents of four hundred and twenty-five stomachs, representing six families, twenty genera* and thirty-three species.

These were all collected by myself or one of my assistants (Mr. W. H. Garman), and labeled at the time with name of species, locality, and date. While the northern half of the State is most fully represented, several trips to southern Mlinois contributed to the material studied and it is believed that the results arrived at are substantially true for our whole area.

Family ETHEOSTOMATIDAE. The Darters.

What the humming-birds are in our avifauna, the "darters" are among our fresh-water fishes. Minute, agile, beautiful, delighting in the clear, swift waters of rocky streams, no group of fishes is more interesting to the collector; and in the present state of their classification, none will better repay his study. Notwithstanding their trivial size, they do not seem to be dwarfed so much as concentrated fishes-each carrying in its little body all the activity, spirit, grace, complexity of detail, and perfection of finish to be found in a perch or a "wall-eyed pike."

They are generally distributed, in suitable streams throughout the State; but we have found them much the most abundant in northern Illinois-in the upper Galena River, in Yellow Creek near Freeport, and in tributaries of the Kishwaukee at Belvidere.

A short and strong minnow-seine of very fine mesh is needed in collecting them. Rapid hauls, made almost on the run, down stream, in swift and shallow water, will be found the most successful. Two or three species, of wider range, will be taken in ordinary situations, in collecting for minnows generally: but the brightest and most characteristic forms can only be got by special effort. $\dagger$

\footnotetext{
- The classification of this paper is substantially that of Jordan's Manual of the Vertebrates of North America, etc., Ed. 2, 1878.

t For a very entertaining and instructive account of these fishes, the reader is referred to papers in the American Naturalist, by Messrs. Jordan and Copeland, Vol. X, pp. 335-341, and Vol. XT, pp. 86-88.
} 
I shall give here a description of the food of the family, based upon a study of the contents of seventy stomachs representing fifteen species, collected in all parts of $\mathrm{Mlli}$ nois, in several months of four successive years. These indicate much more than their number would imply, since from those collected at each time and place, as many were commonly studied as were necessary to give a full idea of the food of the species then and there. The different in. dividuals from the same date and locality usually agreed so closely in food, that the study of from two to five gave all the facts obtainable from several times as many. The data here given, therefore, really exhibit the food of the family at different seasons in twenty-nine localities within the State.

The genus Pleurolepis is comparatively rare in Illinois as there are few of the sandy streams in the State, which it inhabits. Seven individuals were examined-four of $P$. pellucidus and three of $P$. asprellus. The food of these specimens was remarkably uniform-the only elements found being the larvæ of small Diptera and ephemerids. Eighty-one per cent. of the food of all consisted of the larvæ of Chironomus* - a small, gnat-like insect-twelve per cent. of the larvæ of other small Diptera, and the remaining seven per cent. of ephemerid larvæ (May-flies).

T.welve specimens of the genus Alvordius were studied - seven of maculatus and five of phoxocephalus. These represented five different localities and dates. This is a larger species than the preceding, and to this fact is probably due the predominance (seventy-five per cent.) in its food of the larvæ and pupæ of May-flies (Ephemeridæ). These included four per cent. of the larvæ of Palingenia bilineata, Say, one of the largest ephemerids in our streams. The remaining kinds were larva of dragonflies (Agrionidæ), four per cent., larvæ of Chironomus, seven per cent., Corixa tumida, Uhl., thirteen per cent., and Cyclops, one per cent.

\footnotetext{
- The larvæ of Chironomus are among the most important elements of fish food in our waters, appearing in abundance in the stomachs of the young of a great variety of species. They have been too little studied in this country to allow specific determination.
} 
The genus Boleosoma, regarded by Dr. Jordan as the typical darter, was represented by twelve specimens from eight localities-nine of maculatum, two of olmstedi and one of camurum.* These specimens show but slight food differences from other darters of similar size, the only notable variation being the appearance of fifteen per cent. of case-worms (larvæ of Phryganeidæ). Sixty-six per cent. of the food was Chironomus larvæ, seven per cent. larvæ of other minute Diptera, and the remaining twelve per cent. was larvæ of small ephemerids, and a few Cyclops.

I-studied the food of two specimens of Pacilichthys variatus, four of $P$. spectabilis, and two of $P$. asprigenis -making eight of the genus, representing six localities. Fifty-eight per cent. of small larvæ of Diptera (fortynine per cent. of Chironomus), thirty-two per cent. of larvæ and pupæ of small ephemerids, and ten per cent. of case-worms made up the entire bill of fare.

Percina caprodes, the largest of the group, departs from all the foregoing species by the prominence given to crustacean food-thirty per cent. of Entomostraca and three per cent. of the smallest of our Amphipoda, Allorchestes dentata (Smith), Faxon. Most of the Entomostraca were Cladocera, including Daphnia, Euryeercus, and Daphnella. $\dagger$

Here occurred the only instance of molluscan food in the group. One specimen had taken a few individuals of Ancylus rivularis, Say. Reduced ratios of Chironomus and ephemerid larvæ, and a few Corixa tumida complete the list.

Of Nanostoma zonale, less common than the others, but two individuals were examined, and these had eaten nothing but larvæ of small Diptera, including sixty-five per cent. of Chironomus.

* Boleosoma maculatim and B. olmstedi should undoubtedly be united. Specimens in the laboratory collection present the extremes of both forms, together with numerous intermediate stages of each character used to distinguish them.

This whole group exhibits a surprising variability, perhaps due to its comparatively recent origin.

t Daphnella was found in a Percina from the Calumet River, at South Chicago, but not in condition to permit the determination of the species. 
Six specimens of Etheostoma flabellare var. lineolata, from four localities, had eaten sixty-one per cent. of Chironomus larvæ, twenty-seven per cent. larvæ of small ephemerids, and twelve per cent. of Copepoda (Cyelops).

Boleichthys elegans, found only in the southern part of the State (three specimens examined), had eaten only dipterous larvæ (thirty-seven per cent.) and ephemerid larvæ (sixty-three per cent.). This is a larger, heavier species than most of the others, and, therefore, like Alvordius, prefers ephemerids to gnats.

Last and least comes Microperca punctulata, represented by nine specimens from four localities in northern Illinois. This smallest of the darters shares with Pereina, the largest, the peculiarity of a large ratio of crustacean food, which made up sixty-four per cent. of the total. The principal kinds were Cyclops, Chydorus, young Gammarus fasciatus, Say, and young Crangonyx gracilis, Smith. The remaining elements were Chironomus larvæ (thirty-four per cent.) and a trace of ephemerids (two per cent.).

It will be seen that the family, taken as a whole, divides into two sections, distinguished by the abundance or deficiency of crustacean food. This is easily explained by the fact that Percina and Microperca range much more freely than the other genera, being frequently found amrng weeds and algæ in comparatively slow water with muddy bottom, while the others are rather closely confined to swift and rocky shallows.

In discussing the food of the whole group, taken as a unit, it may best be compared with the food of the young of other percoids. It is thus seen to be remarkable for the predominance of the larvæ of Chironomus and small Ephemeridx-the former of these comprising fortv-four per cent. and the latter twenty-three per cent. of the whole food of the seventy specimens. In young black bass (Micropterus pallidus), on the other hand, the averages of nine specimens, ranging from five-eighths inch to one and a half inches in length, were, in general terms as follows: Cladocera forty-two per cent., Copepoda seven per cent., young fishes twenty per cent., Corixa and young 
Notonecta twenty-nine per cent., and larval Chironomus only two per cent. The search for the cause of this difference leads naturally to an examination of the whole economy of these little fishes, and opens up the question of their origin as a group.

The close relation of the Etheostomatidæ to the Perci$d æ$ requires us to believe that the two groups have but recently diverged, if, indeed, they are yet distinctly separate.

We must inquire, therefore, into the causes which have operated upon a group of percoids to limit their range to such apparently unfavorable situations, to diminish their size, to develop unduly the paired fins and reduce the airbladder, to remove the scales of several species more or less completely from the head, breast, neck, and ventral region, and to restrict their food chiefly to the few forms mentioned above.

No species can long maintain itself anywhere which cannot, in some way, find a sufficient supply of food, and also protect itself against its enemies. In the contest with its enemies it may acquire defensive structures or powers of escape sufficient for its protection, or a reproductive capacity which will compensate for large losses, or it may become adapted to some place of refuge where other fishes will not follow. What better refuge could a harassed fish desire than the hiding-places among stones in the shallows of a stream, where the water dashes ceaslessly by with a swiftness few fish can stem? And if, at the same time, the refugee develops a swimming power which enables it to dart like a flash against the strongest current, its safety would seem to be insured. But what food could it find in such a place? Let us turn over the stones in such a stream, sweeping the roiled water at the same time with a. small cloth net, and we shall find larvæ of Chironomus and small ephemerids and other such prey, and little else -food too minute and difficult of access to support a large fish, but answering very well if our immigrant can keep down his size. Here the principles of natural selection assert their power. The limited supply of food early arrests the growth of the young; while every fish which passes the allowable maximum is forced for food to brave 
the dangers of the deeper waters, where the chances are that it falls a prey. On the other hand, the smaller the size of those which escape this alternative, the less likely will they be to attract the appetite of the small gar or other guerilla which may occasionally raid their retreat, and the more easily will they slip about under stones in search of their microscopic game.*

Like other fishes, the darters must have their periods of repose, all the more urgent because of the constant struggle with the swift current which their habitat imposes. Shut out from the deep, still pools and slow eddies where the larger species lurk, they are forced to spend their leisure on or beneath the bottom of the stream, resting on their extended pectorals and anal, or wholly buried in the sand. Possibly this fact is correlated with the absence or rudimentary condition of the airbladder; as it is a rule with many exceptions-but still, probably, a rule-that this organ is wanting in fishes which live chiefly at the bottom.

Doubtless the search for food has much to do with this selection of a habitat. I have found that the young of nearly all species of our fresh-water fishes are competitors for food, feeding almost entirely on Entomostraca and the larvæ of minute Diptera. $\dagger$ As a tree sends out its roots in all directions in search of nourishment, so each of the larger divisions of animals extends its various groups into every place where available food occurs, each group becoming adapted to the special features of its situation. Given this supply of certain kinds of food, nearly inaccessible to the ordinary fish, it is to be expected that some fishes would become especially fitted to its utilization. Thus the Etheostomatidæ as a group are explained, in a word, by the hypothesis of the progressive adaptation of the young of certain Percidæ to a peculiar place of refuge and a peculiarly situated food supply.

Perhaps we may, without violence, call these the mountaineers among fishes. Forced from the populous and fertile valleys of the river beds and lake bottoms, they have

\footnotetext{
- In Boleosoma, which is normally scaled in front of the dorsal fln. we often find the skin of this region bare in large specimens, and showing evident signs of rubbing.

+ Several of the Catostomidæ (suckers) are an exception to this rule. feeding when young chiefly on algæ and Protozoa.
} 
taken refuge from their enemies in the rocky highlands where the free waters play in ceaseless torrents, and there they have wrested from stubborn nature a meager living. Although diminished in size by their continual struggle with the elements, they have developed an activity and hardihood, a vigor of life and glow of high color almost unknown among the easier livers of the lower lands.

The following table (see page 30 ) will facilitate a comparison of the records of the different genera. The percentages were obtained by estimating carefully the ratios of each element of the food of each individual, and averaging these ratios for all the individuals of a species.

Family PERCIDA. The Perches.

This family consists, in this State, of three species-the common yellow perch and the two species of pike-perch or "wall-eyed pike." I have examined the food of seventy-five specimens of this family, so distributed in time and space as to give a satisfactory idea of the usual food.

Perca americana, Schrank. The Common Perch. Ringen Perch.

This exceedingly well-known species is most abundant along the shores of Lake Michigan and in the small streams and lakes of the northeastern part of the State, becoming less common to the south and west. In the Illinois River at Peoria and Henry it occurs in limited numbers, but in southern Illinois disappears so completely that even its name (there generally pronounced "pearch") is transferred to a different family, the sunfishes (Centrarchidæ).

My knowledge of the food of this species is derived from the study of the contents of forty-nine stomachs, of which thirty were from adults and the remaining nineteen from fishes ranging from 13/16 inch to four inches in length. Ten localities and as many dates are represented by these specimens. Some were taken in the Illinois River, others in Lake Michigan and its southern tributaries, and still others in Fox R. at MeHenry, and in the lakes connected with that stream. One lot included 
Detalls of the Food of the Etheostomátida.

\begin{tabular}{|c|c|c|c|c|c|c|c|c|c|}
\hline & $\frac{\frac{\dot{a}}{0}}{\frac{0}{0}}$ & 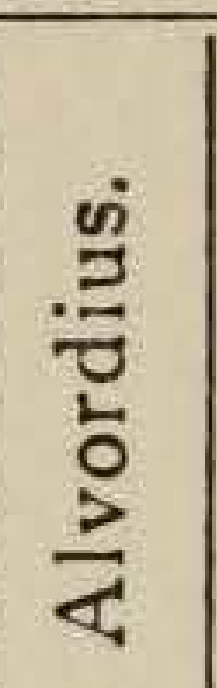 & 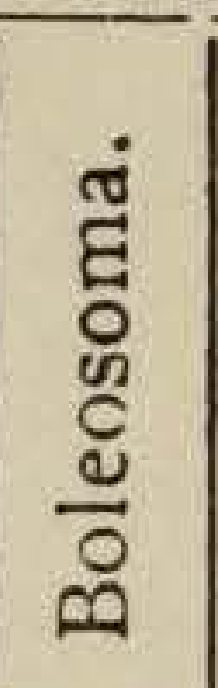 & 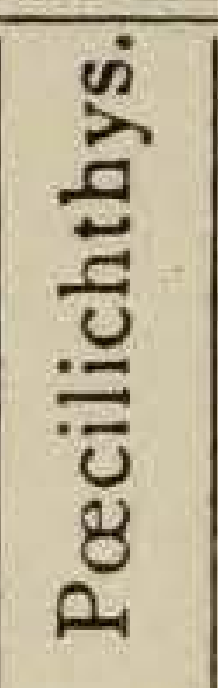 & . & 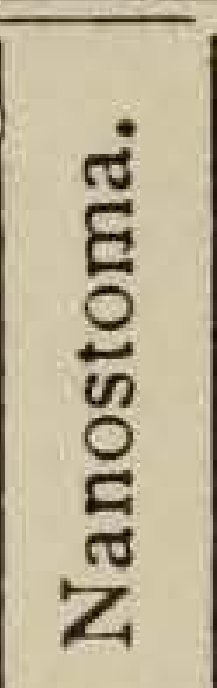 & 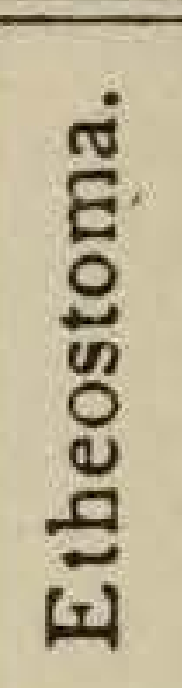 & 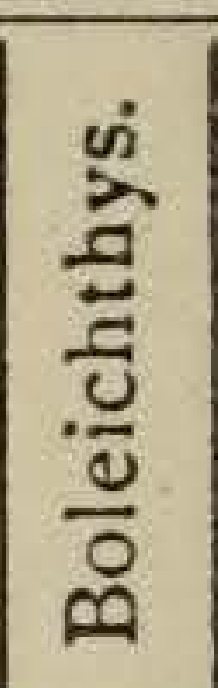 & 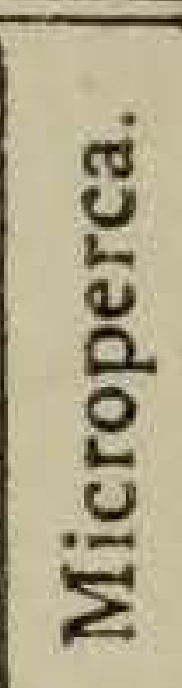 \\
\hline Number of specimens ....... & 7 & 12 & 12 & 8 & II & 2 & 6 & 3 & 9 \\
\hline I MOIJISCA & $\gamma$ & $\cdots \cdot$ & $\cdots$ & $\ldots$ & OI & $\cdots \cdot$ & & 3 & 4 \\
\hline Ancylus & & $\ldots$ & & & OI & & & & \\
\hline II. INS & 100 & 99 & 96 & 100 & 65 & 100 & 88 & 100 & 36 \\
\hline Diptera & 93 & 07 & 73 & $5^{8}$ & 43 & 100 & 61 & 37 & 34 \\
\hline Un & 12 & oI & 07 & $\infty$ & 02 & 35 & & I0 & $\cdots$ \\
\hline Chir & 81 & o6 & 66 & 49 & 41 & 65 & 61 & 27 & 34 \\
\hline Hemipter & $\ldots$ & 13 & ... & .... & 05 & .... & .... & ... & $\ldots$ \\
\hline Cori & $\cdots$ & I3 & $\cdots$ & ... & 05 & .... & … & $\cdots$ & $\cdots$ \\
\hline Undet & $\cdots$ & $\cdots$ & & $\cdots$ & $\mathrm{O} 3$ & & & & .. \\
\hline Uhi............ & $\cdots$ & $\begin{array}{l}07 \\
06\end{array}$ & $\cdots$ & $\begin{array}{l}\cdots \\
\cdots\end{array}$ & $\mathrm{O} 2$ & $\cdots$ & & $\cdots$ & $\cdots$ \\
\hline Neuroptera. & 07 & 79 & 23 & 42 & 17 & $\cdots$ & 27 & 63 & 02 \\
\hline Ephemerid: & 07 & 75 & 08 & 32 & og & .... & 27 & 63 & 02 \\
\hline Pup & $\therefore$. & 08 & & 14 & $\ldots$ & $\cdots \cdot$ & $\cdots$ & & $\cdots$ \\
\hline Larv & 07 & 63 & 08 & 18 & $\infty$ & ... & 27 & 63 & 02 \\
\hline Pal! & $\ldots$. & 04 & $\cdots$ & $\cdots$ & $\cdots$ & $\cdots$ & $\cdots$ & $\cdots$ & $\cdots:$ \\
\hline Agrion & $\ldots$ & 04 & & $\ldots$ & & & .... & $\ldots$ & $\ldots$ \\
\hline Phr & $\ldots$ & $\ldots \ldots$ & 15 & 10 & 08 & $\ldots$. & $\cdots$ & $\ldots$ & \\
\hline & $\ldots$ & oI & 04 & $\ldots$ & 33 & $\ldots$ & 12 & $\ldots$. & 64 \\
\hline 1. Amphipod & $\cdots$ & $\cdots$ & $\cdots$ & $\cdots$ & 03 & $\cdots$ & $\cdots$ & $\cdots$ & 12 \\
\hline Gar & .. & $\cdots$ & $\cdots$ & $\cdots \cdots$ & $\cdots \cdot$ & ... & $\cdots \cdot$ & $\ldots$ & 06 \\
\hline & • & $\cdots$ & $\cdots$ & ... & $\cdots$ & $\ldots$ & $\cdots$ & $\ldots$ & 06 \\
\hline Allorchestes dentat & . & $\cdots$ & $\cdots$ & $\ldots$ & $\mathrm{O} 3$ & $\ldots$ & $\ldots$ & $\ldots$ & $\cdots$ \\
\hline 2. Clado & & $\ldots$ & $\ldots$ & ... & 24 & & $\ldots$ & $\ldots$ & 27 \\
\hline & & & & $\ldots$ & 05 & $\ldots$ & $\cdots \cdot$ & $\ldots$ & $\ldots$ \\
\hline Dap & & $\cdots$ & & . & 06 & $\cdots$ & .... & $\cdots$ & $\cdots$ \\
\hline Sidid & * & & & & 07 & & $\cdots$ & $\cdots$ & \\
\hline $\begin{array}{l}\text { Sidida } \\
\text { Daph! }\end{array}$ & & & & $\cdots$ & 05 & $\cdots$ & $\cdots$ & $\cdots$ & $\cdots$ \\
\hline Lynceid & & $\cdots$ & & $\begin{array}{l}\cdots \\
\cdots \cdots\end{array}$ & $\begin{array}{l}05 \\
01\end{array}$ & $\begin{array}{l}\cdots \\
\cdots\end{array}$ & ?... & $\cdots$ & o3 \\
\hline & & & & & $\cdots$ & $\ldots$. & $\ldots$ & $\ldots$ & 24 \\
\hline & .. & & & $\ldots$. & OI & $\ldots$ & $\ldots$ & $\ldots$ & $\ldots$ \\
\hline \multirow[t]{6}{*}{3.} & & & & $\ldots$. & OI & $\cdots$ & .... & $\ldots$ & \\
\hline & & & & & ỌI & $\cdots$ & $\cdots$ & $\cdots$ & ob \\
\hline & & & & $\cdots$ & 01 & $\cdots$ & ... & $\cdots$ & 06 \\
\hline & & oi & 44 & $\begin{array}{l}\cdots \\
\cdots\end{array}$ & $\ddot{0}$ & & 12 & $\cdots$ & io \\
\hline & & OI & 01 & .... & 05 & $\ldots$ & 12 & $\cdots$ & I9 \\
\hline & & $\cdots$ & & ....... & OI & & & & \\
\hline
\end{tabular}

in these notes was bought in the Chicago market. They were evidently of the river form of the species, and judging from the contents of their stomachs, which included a crustacean* not known to occur in Illinois but found abundantly in Michigan, I conclude that they were from that state or from Wisconsin. 


\section{Food of the Young.}

Finding that the food of most fishes differs with age, I have grouped the young according to size, and averaged the food for each group separately-the first group consisting usually of those under an inch in length, the second of those from one to two, etc.

Two perch under an inch in length had eaten nothing: but Entomostraca-about equal quantities of Cyclops and Daphnias. It was not until the specimens reached an inch and a half in length that insects of any considerable size appeared in the food. A single smaller fish had eaten a few minute larvæ of Chironomus, but otherwise the food at this age consisted wholly of Entomostraca.

About thirty-four per cent. of the food of nine specimens ranging from $1 \frac{1}{8}$ to two inches in length consisted of insects, and sixty-six per cent. of crustaceans. The only insects recognized were the larvæ and pupæ of Chironomus (eleven per cent.), small water-bugs-Corixa tumida, Uhl., C. alternata, Say, etc. (twenty-three per cent.)and a trace of larvæ of May-flies (Ephemeridæ). The Crustacea were chiefly Cladocera and Copepoda-thirtysix per cent. and twenty-four per cent. respectively. Four of the nine had eaten small quantities of a small amphipod crustacean, Allorchestes dentata, which is very abundant north, and has, in fact, about the same distribution in the State as the perch itself. The Cladocera were chiefly Daphniidæ (twenty-seven per cent.), including Daphnia pulex, L., Simocephalus americanus, Birge, and Bosmina longirostris. Specimens of Chydorus and Pleuroxus made up the principal part of the nine per cent. of Lynceidæ eaten. The Copepoda were all Cyclops and Diaptomus.

Four specimens two and a half inches long, all taken at Peoria in November, 1878, had eaten nothing but Hemiptera (twelve per cent.) and Neuroptera (eighty-eight per. cent.). The Hemiptera were all Corixa alternata, and the Neuroptera were nearly all the extremely common larva of one of our most abundant May-flies (Palingenia bilineata, Say). Larvæ of small dragon-flies (Agrionini) made five per cent. of the food. The simplicity of the 
food of these specimens is probably due partly to the fact that they were all caught at the same time and place, and partly to the wintry weather when they were taken.

Four specimens, from three and a half to four inches long, representing two localities and dates, had eaten a greater variety of articles, the food, in fact, now elosely approaching that of the adult. Forty-five per cent. of the food was insects-chiefly larvæ of May-flies-and fiftyfive per cent. Crustacea-chiefly Amphipoda and Cladocera. Other insect elements were larvæ of Chironomus, six per cent., and four per cent. of Corixas. The Cladocera were all Daphnia, and the Amphipoda were Allorchestes dentata. A single specimen from Long L., near Pekin, IIl., had eaten an isopod crustacean (Asellus). Cyprididæ, another family of minute crustaceans, formed eight per cent. of the whole food of these specimens.

\section{Food of the Adult.}

The thirty mature individuals may best be treated in two groups, the first from streams and the second from Lake Michigan.

Four of the first group were bought in the Chicago market, in March, 1880; six were taken from the upper Fox, in May; four were from Calumet R. at South Chicago, taken in August, 1878, and four were caught in October of that year, from the Illinois at Peoria.

We notice, first, the entire disappearance of Entomostraca, which are thus seen to be food proper to the young. We next observe the appearance of Mollusea (nineteen per cent.), which are evidently no insignificant food resource of the species. Unio, Cyclas, Succinea, Physa heterostropha, Say, and Valvata tricarinata, Say, are the mollusks recognized. Notwithstanding the lack of Entomostraca, Crustacea are the most important resource of these river specimens, constituting forty-eight per cent. of their food. Crawfishes (Cambarus) and our common little fresh-water shrimp (Palamonetes exilipes, St.) compose ten per cent. of the whole; the previously noticed Allorchestes amounts to fifteen per cent.; and species of Asellus, and Mancasellus tenax to twenty-three per cent. The Mancacelli were all from the specimens 
from the Chicago market. Insects are also an important item-amounting to twenty-four per cent., nearly all being the larvæ of Neuroptera-Mayflies (Ephemeridæ), dragon-flies and ease-flies (Phryganeidæ). A single specimen from Peoria Lake had eaten one small fish-a "darter" of the genus Pœcilichthys.

The second group, twelve specimens from Lake Michigan, presents a curious and instructive contrast in food to the foregoing. Mollusks and insects wholly disappear, and Crustacea are limited to the commonest crawfish of the lakes (Cambarus virilis, Hagen), which forms fourteen per cent. of the food. The remaining eighty-six per cent. consisted wholly of fishes, all minnows (Cyprinidæ) so far as recognized except one, and that was some undetermined percoid--probably itself a perch.

It will thus be seen that the common perch has a food history of three periods - the periods of infancy, youth, and mature age. In the first it lives wholly on Entomostraca and the minutest larvæ of Diptera; in the second, commencing when the fish is about an inch and a half in length, it takes up first the smaller and then the larger kinds of aquatic insects in gradually increasing ratio, the entomostracan food at the same time diminishing in importance; and in the third it appropriates, in addition, mollusks, crawfishes and fishes-in the lake specimens depending almost wholly on the last two elements.

We have here the first instance of a fact which we shall see again and again illustrated-that the young, having at first an alimentary apparatus too small and delicate to dispose of any insects but the minutest larvæ, live almost wholly on minute crustaceans.

It is proper to note that the lake and river pereh are by some good authorities regarded as separate species-the latter being much more highly colored than the former. I have not found so strict a separation of the two forms as that described by Mr. E. W. Nelson, but have frequently taken both in the same haul of the seine in different parts of Calumet R. and in Lake George, Ind.--a body of water communicating with Lake Michigan by an outlet three or four miles long. Occasional pale specimens are also taken far from the lakes, in the Fox and Illinois rivers. The 
difference in color is probably due partly to the smaller amount of light to which those inhabiting the deeper waters of the lake are exposed, and partly to their piscivorous habit combined with the comparatively few lurking places afforded them. There is some evidence that fish food bleaches a fish directly, and a good deal that it does so indirectly, by increasing the importance of an inconspicuous appearance.

Stizostethium canadense, Smith. Gray Pike-Perch. SaUger. "JaCK-SAlmon."

Fourteen specimens of this excellent fish were examined, all of which were from the Illinois R., ten taken in October, 1878, one in June, 1877, and three in November, 1877. It is evidently a very destructive species. These specimens had eaten nothing but fishes. In three cases these were unrecognizable, and in two others I could only tell that they were Acanthopteri. Four of the remaining "pike" had eaten hickory-shad (Dorysoma cepedianum), two had eaten catfish (Siluridæ) of which one was an Amiurus, two had eaten sheepshead (Haploidonotus grunniens), and one had taken a black bass and some sunfish (Centrarchidæ). The presence in the stomach of one of these fishes, of a catfish of medium size, with its poisonous pectoral and dorsal spines unbroken, was a striking illustration of the gastric energy of this species.

Stizostethium vitreum, Mitch. Pike-Perch. Wald-eyed Pike. "Salmon."

This is far the finest of our river fishes-second to no fresh-water species except, possibly, some of the salmon family. It occurs in the great lakes, and throughout the State generally in the larger streams. It is a much larger fish than the preceding, not infrequently reaching a weight of twenty pounds. Certainly no fish of our waters is better deserving of attention than this. The only drawback to its increase is in its voracity; but, although it devours an immense number of other fishes, there is no evidence that it is wantonly destructive or that it eats more in proportion to its weight than the black bass. 
Twelve of this species were examined, two of which were under three inches in length, and the others adult.

\section{Food of the Young.}

A specimen two inches long, taken in the Illinois R., at Pekin, June 2, 1880, had eaten only a minute fish. One, two and a half inches long, taken at the same place in June, 1878, had also eaten a small fish and a few Entomostraca (Cyprididæ and Daphniidæ). The appearance of these Entomostraca in the food of a fish of this size, makes it altogether probable that Stizostethium, like Perca, wholly depends on these minute Crustacea, when very young.

\section{Food of the Adult.}

The remaining specimens, taken from three localities, had eaten nothing but fishes, one-half of them only the hickory-shad or skip-jack (Dorysoma cepedianum). In one other specimen, this species was associated with a minnow (Cyprinidæ), and in still another with a small sunfish with three anal spines (Centrarchidx). One of the remaining stomachs contained only an unrecognizable fish, and the other two contained Cyprinidæ, including the creek chub, Semotilus corporalis.

The two species of this genus agree so closely in food that they may well be discussed together. Apart from their exclusively piscivorous habit, the most interesting fact shown is the importance of the hickory-shad as food for this fish. We shall find accumulating evidence that this shad, utterly useless for human food, is, notwithstanding, one of the most valuable fishes in our streams. Nevertheless, not the slightest attention is paid to its preservation, much less to its encouragement. The fishermen commonly regard these fishes as a mere nuisance, and leave them to die on the bank by hundreds, rather than take the trouble to return them to the water. They are a very delicate species, and are easily killed by rough handling in the seine, but the majority of those captured might be saved with a little care.

The abundance of these fishes as compared with some other species in the river might seem to indicate that they 
are common enough as it is. Few realize, however, the number of fishes needed to feed a pike-perch to maturity. Two or three items from my notes will furnish the basis for an intelligent estimate of this number.

From the stomach of a Stizostethium canadense caught in Peoria Lake October 27, 1878, I took ten well-preserved specimens of Dorysoma, each from three to four inches long; and from a Stizostethium vitreum I took seven of the same species, none under four inches in length. As the Dorysoma is a very thin, high fish, with a serrate belly, these were as large as a pike-perch can well swallow; and we may safely suppose that not less than five of this species would make a full meal for the pikeperch. The species is a very active hunter, and it is not at all probable that one can live and thrive on less than three such meals a week. The specimens above mentioned were taken in cold autumn weather, when most other fishes were eating but little; but, since fishes generally. take relatively little food in winter, we will suppose that the pike-perch eats, during the year, on an average, at this rate per week for forty weeks, giving us a total per annum of six hundred Dorysomas destroyed by one pikeperch. We cannot reckon the average life of a Stizostethium at less than three years, and it is probably nearer five. The smallest estimate we can reasonably make as to the food of each pike-perch would therefore be somewhere between eighteen hundred and three thousand fishes like Dorysoma. A hundred pike-perch, such as should be taken each year along a few miles of a river like the Illinois, would therefore require one hundred and eighty thousand to three hundred thousand fishes for their food. Finally, when we take into account that a number of other species also prey upon Dorysoma, and that the whole number destroyed in all ways must not exceed the mere surplus reproduced-otherwise the species would be extinguished-we can form some approximate idea of the multitudes in which the food species must abound if we would support any great number of predaceous fishes. Dorysoma, being a mud-eater and a vegetarian, taking animal food only during the entomostracan 
period, can probably be more readily maintained in large numbers in our muddy streams than any other fish.

It is evident that the increase of edible fishes without a corresponding supply of food will be largely time and labor thrown away. Probably if protected from wanton and ignorant destruction, the Dorysoma would abound sufficiently, as it is enormously prolific.

The following table is similar to that given for the preceding family. The mark + is used to indicate the occurrence of an element in too small an amount to figure in the ratios. 
Table of the Food of the Percid $\pi$.

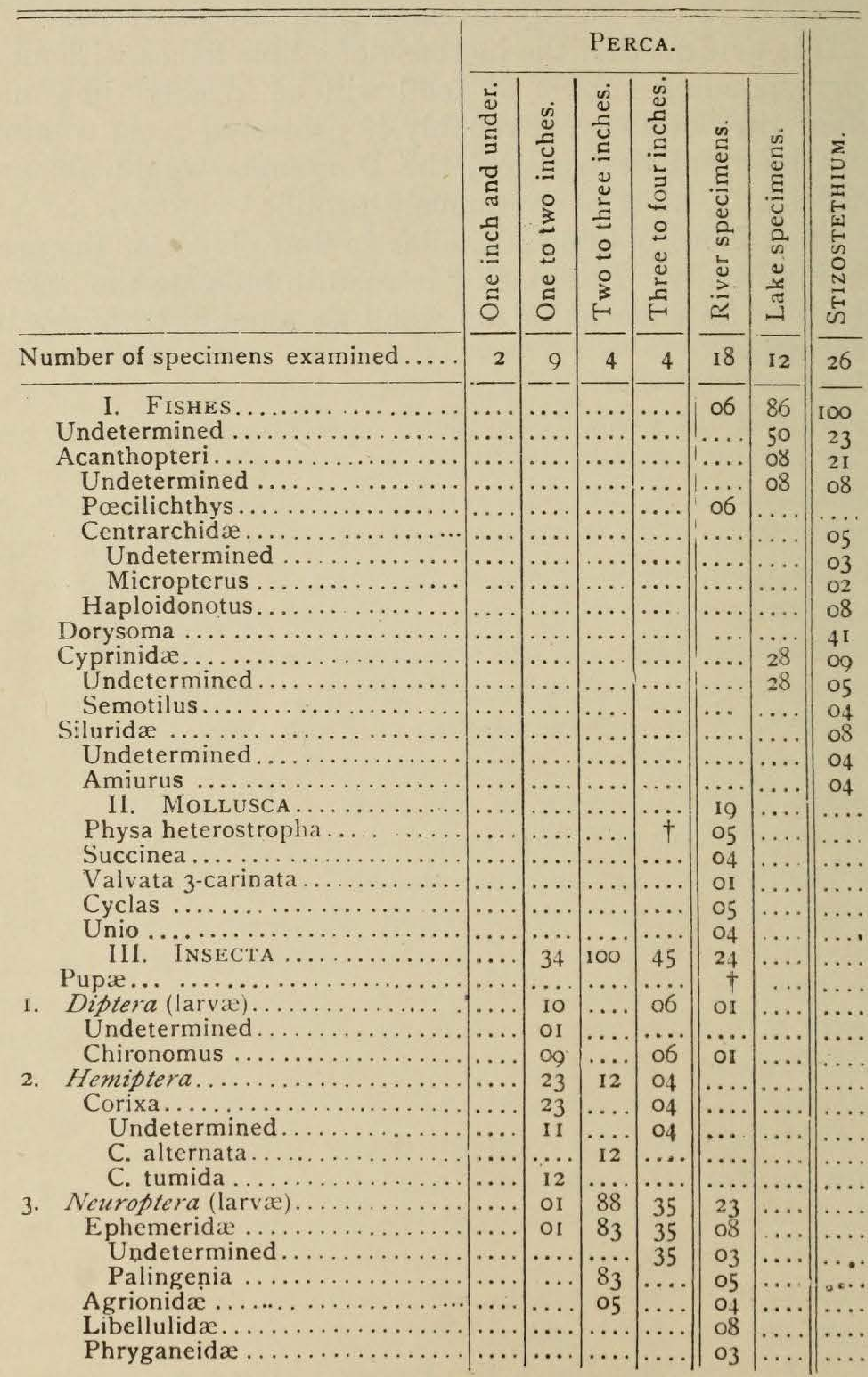


TABle of the Food of Percid A-Continued.

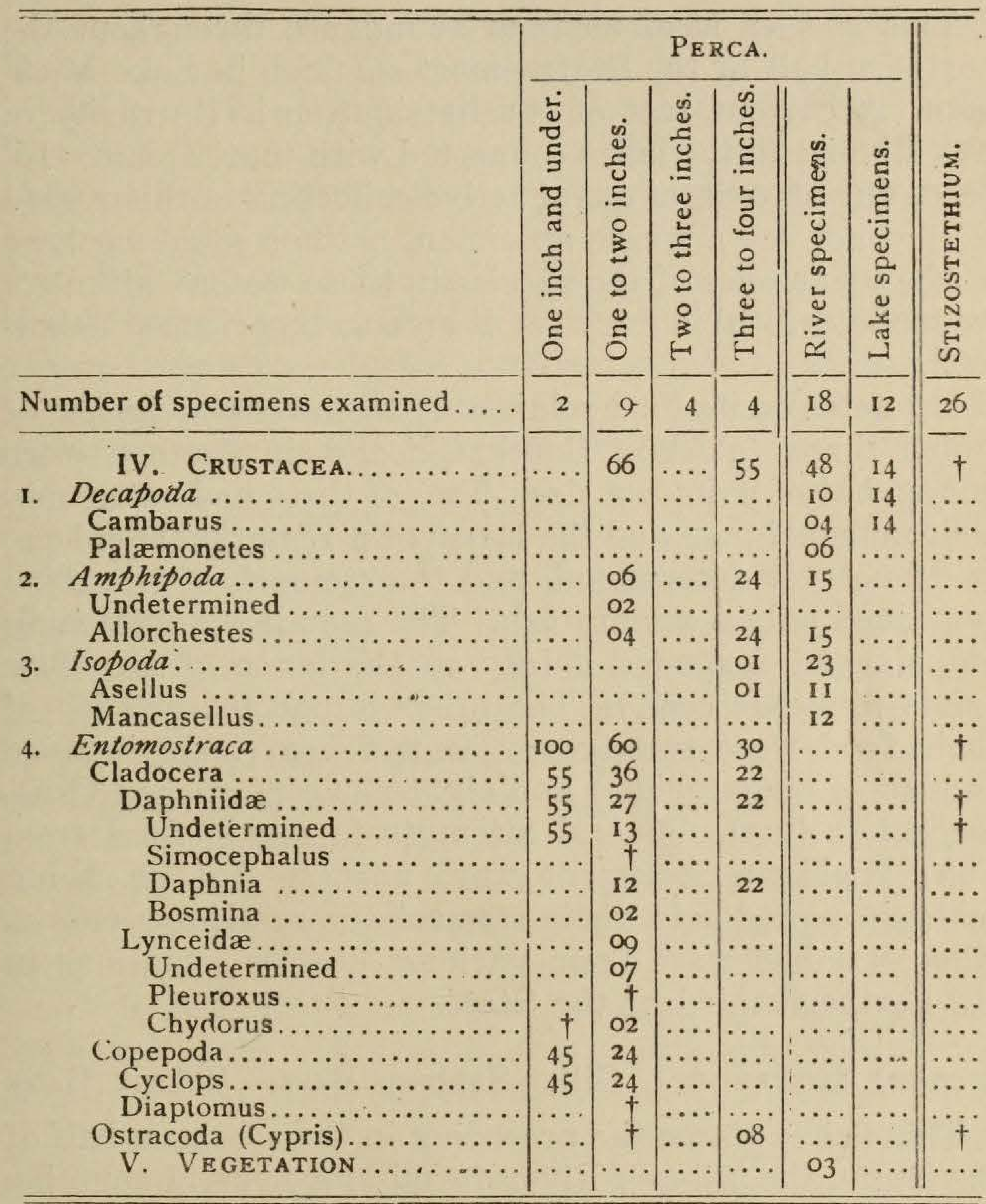

Family LABRACID丑. The Bass.

We have but two species of this family, the white bass and the brassy bass (Roccus chrysops and Morone interrupta). As far as their food is concerned, these are evidently equivalent species, agreeing closely in their general relations, and differing only in their distribution. 
Roccus chrysops, Raf. White Bass.

This species is of medium abundance throughout the northern half of the State-most common in Lake Michigan. A curious fact of its distribution is its rarity in Fox River and the lakes connected with that stream. Indeed, during several days' active collecting in this region we did not see a single specimen, neither could we hear of the occurrence of the species in those waters, although we rnade careful inquiry for it among experienced fishermen.

My notes on its food relate only to eleven specimens, of which three, taken at South Chicago, in August, were young, but of unknown size. Two of these had eaten only Chironomus larvæ and the larvæ of a remarkable ephemerid? not yet determined, and the stomach of the third contained only a minute fish. The remaining eight individuals had depended chiefly on the larvæ of May-flies (sixty-nine per cent.). The other important articles of their food were twenty per cent. fishes (including one sunfish-Centrarchidæ) and eight per cent. isopod Crustacea (Asellus). Several attempts to secure food from Lake Michigan specimens were unsuccessful, as, being taken in pound-nets, their stomachs were always empty. Those studied were from various interior situations in the northern third of the State.

Morone interrupta, Gill. Striped Bass. Brassy Bass.

This fish replaces the preceding in the southern half of the State, the Illinois River forming a neutral zone between the respective territories of the two species.

The food of six specimens of this species was studied, all taken from the Illinois River from May to October.

Four of these were young. The smallest, one and a fourth inches long, taken at Peoria, in June, 1878, had eaten about equally of small Dorysoma cepedianum and Entomostraca-forty per cent. Leptodora and ten per cent. Cyclops. One, an inch and a half in length, taken at the same time and place, had eaten only Dorysoma, with a trace of Cyclops. The next, one and five-eighths inches in length, had eaten a small undetermined fish and 
a few Daphnias. The fourth, one and seven-eighths inches long, caught at Peoria, in October, had eaten only larvæ and pupæ of Chironomus.

The two adult specimens were feeding chiefly upon the larvæ of Neuroptera-especially May-flies. An Allorchestes dentata and a few small grasshoppers also appeared in the food.

It will be seen that this species apparently agrees closely with the preceding in its food. The large amount of crustacean food in the smallest specimen shows that we should probably find still smaller Labracidæ depending upon these as strictly as the Percidx.

\section{Family CENTRARCHIDAE. The Sunfishes.}

This interesting group, known, in some of its members, to every one who has ever seen a dozen fishes, is represented in Illinois by sixteen species, as the species of this family are now understood. The two black bass, included in this family for technical reasons, are, of course, the most important species. The rock bass, the croppie and the common sunfish (Lepiopomus pallidus), although not fishes of the first class, would be seriously missed if we were to lose them; and boyhood in the country would be quite another thing if it were not for the "pumpkinseed" in the mill-pond, whose barbaric splendor thrills the heart of the youthful fisherman as the more delicate beauties of the trout or salmon do those of tougher fibre.

I have studied the food of thirteen species of this group, as indicated by two hundred and thirty-seven specimens, well distributed in time and area.

Decided differences in food made out in the various genera, have been found to coincide with differences in a few structures about the mouth in such a way that one may predict, from an examination of these structures, what the leading peculiarities of the average food of any genus will be.

Micropterus pallidus, Raf. Large-mouthed Black Bass.

This famous species is too well known to require extended comment. The ordinary fishermen rarely distin- 
guish it from the following; and, indeed, sportsmen do not always recognize the difference.

I have examined the food of thirty-one specimens of this species, fourteen of which were adults, and the remainder young, of different ages.

\section{Food of the Young.}

The first group, consisting of five specimens under one inch in length (ranging from $\frac{5}{8}$ to $\frac{3}{4} \mathrm{in}$.), represents three localities-Crystal Lake, in McHenry county, the Illinois River at Pekin, Tazewell county, and the same stream at Starved Rock, in LaSalle county. They were taken in June, July and August of three different years. It is evident, therefore, that the common features of their food cannot well be attributed to any other than their similar size.

The entire food of these fishes consisted of small Crustacea-all Entomostraca except seven per cent., eaten by a single fish, which consisted of the very young of some undetermined amphipod-probably Allorchestes. Eightyseven per cent. of the food was Cladocera, principally Bosmina longirostris, Müll. Simocephalus americonus, Birge, was also an important element; and traces appear of Chydorus, Pleuroxus and Eurycercus lamellatus. About six per cent. of Cyclops had been eaten.

In the food of the next group-six specimens, from $1 \frac{1}{1}$ to $1 \frac{1}{2}$ inches long-minute fishes and insects appear. The fishes (twenty-nine per cent.) were not large enough to determine. The insects (forty-six per cent.) were mostly young water-bugs (Corixa), the principal part of which were about half grown. The adults were all Corixa tumida, Uhl. The Entomostraca drop to twenty-five per cent., ahout equally Cladocera and Cyclops. Among the former were many specimens of Simocephalus americanus, and a few of the rare and curious Leptodora mentioned in a previous paper.* The specimen in which this was found was taken at Peoria, in June, 1878. All of this group were taken from the Illinois River, but at different places and dates. Some, taken at the same place and

\footnotetext{
* See Bull. No, 2, Ill. State Lab. Nat. Hist., p. 88.
} 
time as others of the preceding group, .differed from them in the smaller number of Entomostraca eaten, and the larger number of insects-differences evidently only to be explained as due to the different sizes of the fishes.

The next two specimens, between two and three inches long, had eaten only insects, chiefly Corixa tumida.

Four specimens, ranging from three to three and a half inches in length, all taken from a lake in the Illinois River bottom, in October, 1879, had eaten nothing but insects-almost wholly Corixas and the larvæ of May-flies (Ephemeridx). The Corixas were C.alternata, Say, and C. tumida, Uhl.

\section{Food of the Adult.}

Turning to the food of the fourteen adults, we note the total disappearance of Entomostraca, the merely accidental occurence of insects, the appearance of crawfishes (Cambarus immunis), which amount to seven per cent. of the whole food, and the great predominance of fishes (eighty-six per cent.). These were of sufficient variety to show that no group is safe from the appetite of the bass unless it be the gar.

Perch, minnows, eatfish and hickory-shad were recognizable. The last were much the most abundant, occurring in eight of the specimens, and constituting fifty-eight per cent. of the food of the whole number. They ranged from three to six in each stomach, and were from three to four inches long. It should be noted, however, that these were all eaten by fishes taken at the same place and time. A large mouse was found in the stomach of one bass from the Illinois River.

We may generalize these data by saying that this black bass lives, at first, wholly on Entomostraca; that it commences to take the smallest aquatic insects when about an inch in length, and that minute fishes appear in its diet almost as early. From this forward, the Entomostraca diminish in importance, and the insects and fishes become larger and more abundant in the food. The adults eat voraciously of a great variety of fishesespecially the hickory-shad (Dorysoma) - and feed upon crawfishes also to some extent. 
Micropterus salmoides, Lac. Small-mouthed Black BAss.

This species, called also tiger bass, river bass, etc., is the black bass par excellence. It ranges usually in deeper and clearer water than the preceding; but both are often taken together.

I have made full notes of the food of twenty-seven specimens-three adult and the others young. I had none of this species under an inch in length; but, judging from the general resemblance of the food of this and the preceding bass at later ages, I do not doubt that this will also be found to feed at first on Entomostraca, although insect food is possibly more important to it from the beginning.

Seven individuals, from one to two inches in length, were all taken in July from rocky ripples in the Fox River, at Dayton, Ill., a few miles above the mouth of the stream. These had eaten only five per cent. of Entomostraca-the whole remainder of the food consisting of insects, of which Corixa tumida, young and adult, and larvæ of May-flies and darning-needles (Agrionidæ) were the most important kinds. Four per cent. of the larvæ of Chironomus are worthy of notice. The scarcity of Entomostraca in the food of fishes as small as these is probably due to the situation in which these specimens occurred, as few Entomostraca are to be found in swift water. The same fact will account for the presence of Chironomus larvæ-found abundantly under stones in rapid streams.

The next ten specimens, between two and three inches long, were taken in July, partly at the same place as the preceding, and partly from the Illinois River, a few miles below the mouth of the Fox. These differed from the smaller specimens chiefly in the appearance of fishes in the food (five per cent.) and in the absence of Neuroptera. Probably the last of these differences, at least, was accidental. A few larvæ of aquatic Coleoptera (Hydrophilidæ and Dytiscidæ) were noticed. Corixas, including C. tumida, Uhl, and C. signata, Fieb., ${ }^{*}$ amounted to eighty-two per cent. of the food.

In those ranging from three to four inches in length (seven individuals), the fishes eaten rise to fourteen per 
cent., but the insects drop away to seven per cent., and the Crustacea rise to seventy-nine. Here, however, difference of locality interferes to prevent any satisfactory comparison with other ages - as these specimens were all taken in August, from Calumet River, at South Chicago. This slow stream, clogged with Algæ and a great variety of other aquatic plants in midsummer, also swarms with Crustacea-especially the little Allorchestes dentata. This species made sixty-three per cent. of the food of these specimens ; and an undetermined species of Asellus, fourteen per cent. A few Gammarus fasciatus were also found. The insects were Corixa and larvæ of Agrionidæ.

It will be seen that, excepting the gradual increase of the number of fishes eaten, these data show no especial difference in the young of different ages. Smaller specimens and a larger number from a greater variety of situations, would be necessary to exhibit this difference.

The food of the young as a whole, apparently, does not differ essentially from that of the large-mouthed species, except in the probably greater importance of the insect element-especially Corixas, which in these twenty-four specimens amounted to fifty per cent. of the food-and the inferior importance of fishes.

This peculiarity is expressed in a slightly different manner in the food of the adult. The three specimens examined had eaten only fishes (Noturus flavus and Percina caprodes) and crawfishes (Cambarus propinquus) - thirty-eight per cent. of the former and sixtytwo per cent. of the latter.

This is the first of several instances in which the ratio of fishes in the food of allied species and genera was found to correspond to the size of the mouth, being largest in those with the largest oral opening.*

*The frequency with which these two species of black bass are confounded makes it desirable that a single reliable character should be selected by which they can be invariably distinguished, whatever the age of the specimen. This character is afforded by the size of the scales, the small-mouthed species having the smaller scales. In this species there are eleven longitudinal rows of scales between the dorsal fin and the row of perforated scales running along the middle of the side. called the lateral line. In the large-mouthed species, there are never more than nine such rows. The young are easily distinguished by the longitudinal black stripe along the side of the large-mouthed bass, which is wanting in the young of the other species. 
The Food of Fishes.

Table of the Food of Micropterus.

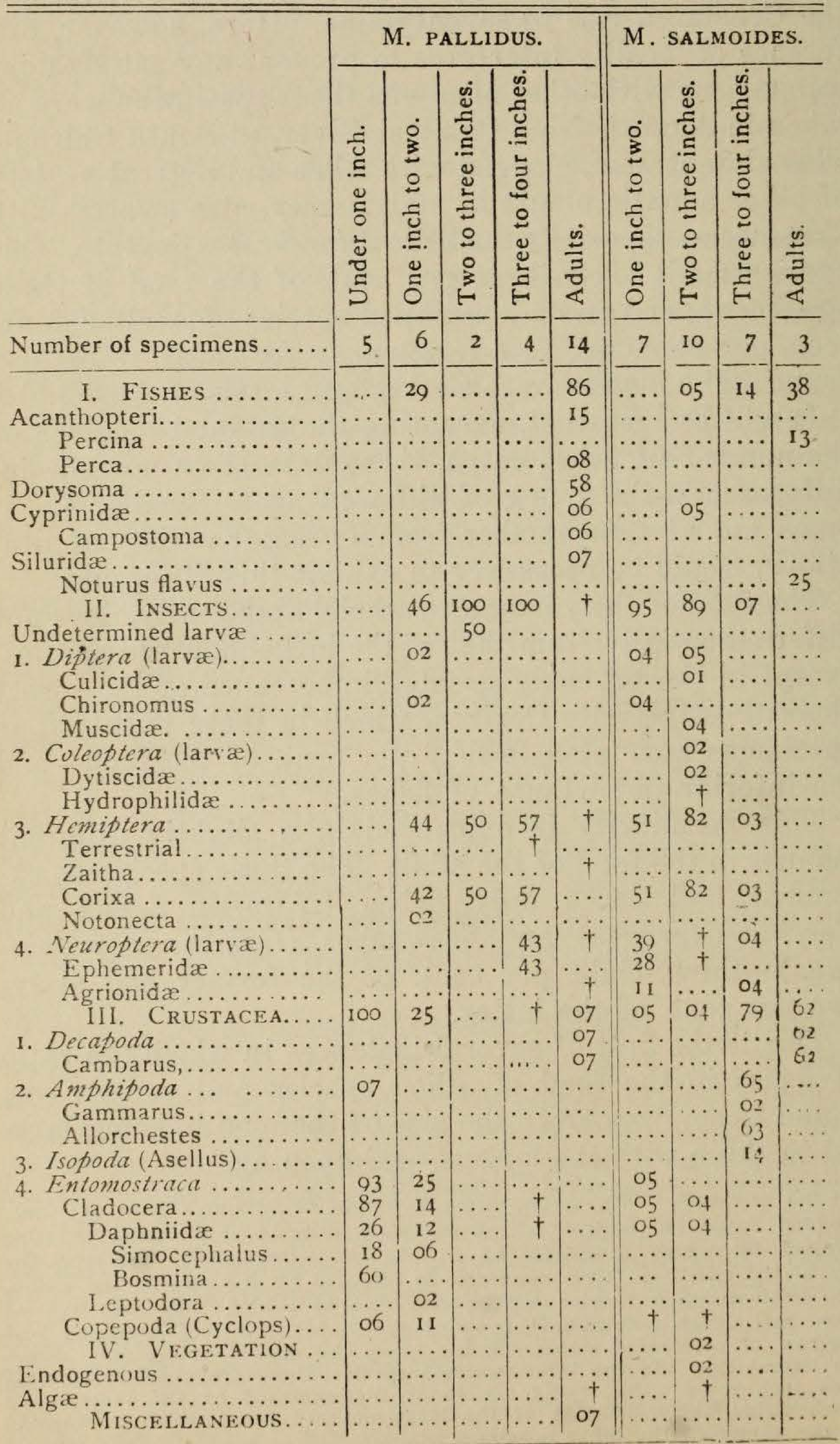


A mbloplites rupestris, Raf. Rock Bass.

This favorite and widely distributed species does not differ from the other fishes mentioned in respect to the food of the young. The smallest specimen examined, fiveeighths of an inch long, contained only a few Cladocera (Pleuroxus). Another, three-fourths of an inch long, had eaten Daphnids (seventy-five per cent.), Cyclops (ten per cent.), and larvæ of Chironomus. A third, seven-eighths of an inch long, contained only minute fragments of a few larvæ of Neuroptera. These specimens were all taken from Fox River in July, 1879. The remaining young of the year were living chiefly on Corixa (eighty-three per cent.), as were also the young of the year preceding (ninety per cent.), so far as could be judged from the food of two specimens, from three to four inches in length. Some land insects, ephemerids, water-beetles, and a few Allorchestes were also found in the food.

Four adult specimens, taken at Ottawa on the 8th of July, had eaten some minute fishes (fifteen per cent.), a few water-beetles, including Tropisternus limbatus, over forty per cent. of Neuroptera larvæ, and about thirty per cent. of small crawfishes. The Neuroptera included Baëtis and other ephemerids (twenty per cent.), Agricn. idæ and large Libellulidæ, and fifteen per cent. of caseflies (Phryganeidæ). Pond-weed (Potamogeton) found in two stomachs, had probably been taken accidentally.

Chanobryttus gulosus, C. \& V. Wide-mouthed Sunfish.

This fine species is among the commonest of the family in the lakes and ponds of southern Illinois, where it is commonly known as the "goggle-eye."

The northern limit of its range, so far as known, is the Illinois River valley. In number and habitat it replaces in the south the Eupomotis aureus of the north; but this equivalence is only apparent as the two species differ widely in food. From its size and abundance, it is no insignificant food resource.

\section{Food of the Young.}

My smallest specimens were from lakes in the Mississip- 
pi bottom, near Bird's Point, Missouri. Two of these, one inch long and under, taken in September 1879, had eaten only Bosmina longirostris and Cyclops. Insect food first appears in specimens one and one-half inches long. Eight specimens, between one and three inches long, six of which were taken from a lake in the Illinois bottoms, near Pekin, in October, 1879, and two from a lake in Kentucky, near Cairo, Illinois, had eaten about forty per cent. Entomostraca, thirty per cent. Neuroptera larvæ, and thirty per cent. Corixas and Diptera larvæ. Daphnia pulex, Simocephalus americanus, Bosmina longirostis, Chydorus, Pleuroxus and Cyclops, were among the Entomostraca. Corixa alternata was found among the Hemiptera. Most of the Diptera (i. e., fifteen per cent.) were larval Chironomus.

\section{Food of the Adult.}

Six adults from rivers, streams and lakes in central and southern Illinois, show the usual change in food, carried farther than in the preceding species. Entomostraca disappear-except a few Chydorus in a single specimen-and fishes become the principal reliance, amounting to forty-seven per cent. of the food. Corixas, larvæ of Palingenia bilineata, and some terrestrial ColeopteraAnomala binotata-which made half the food of one specimen, are the remaining items.

The especially piscivorous habit of this species is probably related to the size of its mouth, which is much the largest among the sunfishes proper. A similar relation has already been noticed between the two black bass. 
Table of Food of Ambloplites and Chanobrytus.

\begin{tabular}{|c|c|c|c|c|c|c|c|c|}
\hline & \multicolumn{4}{|c|}{ AMBLOPLITES. } & \multicolumn{4}{|c|}{ СИЕNOBRYTTUS. } \\
\hline & 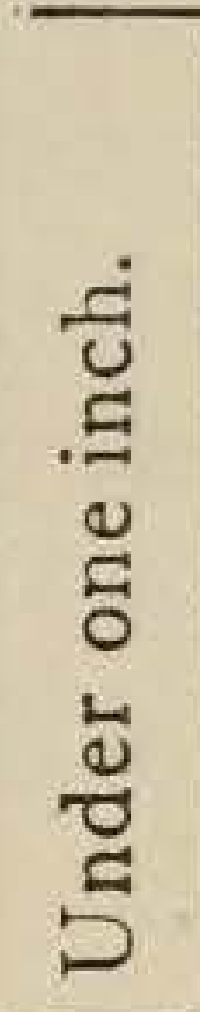 & 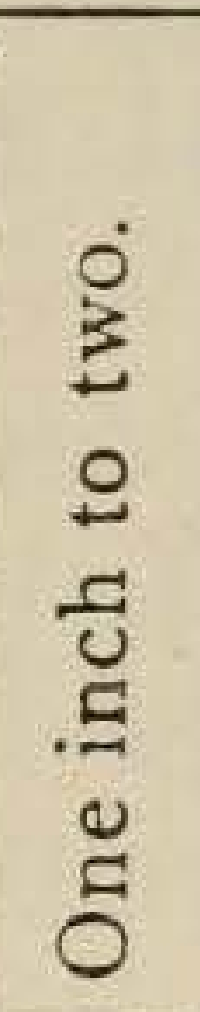 & 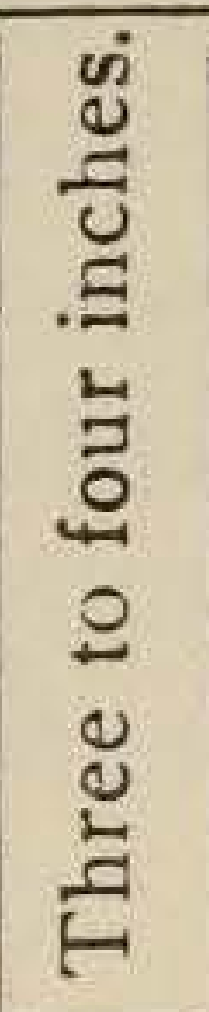 & 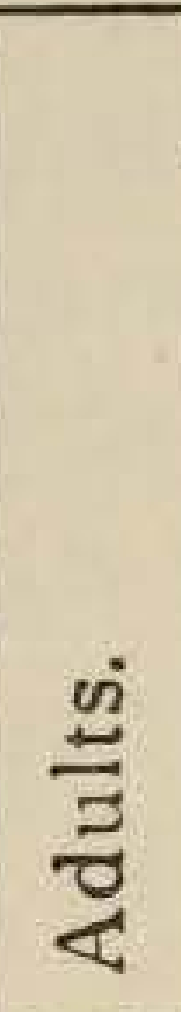 & 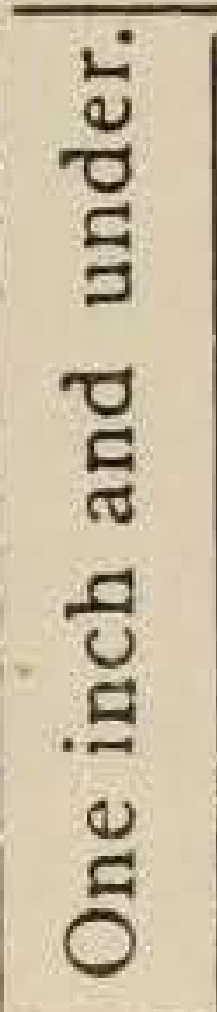 & 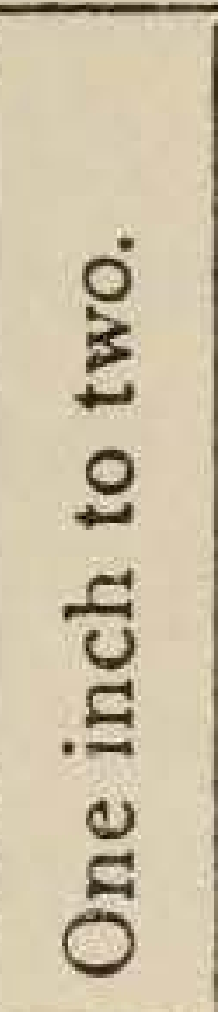 & 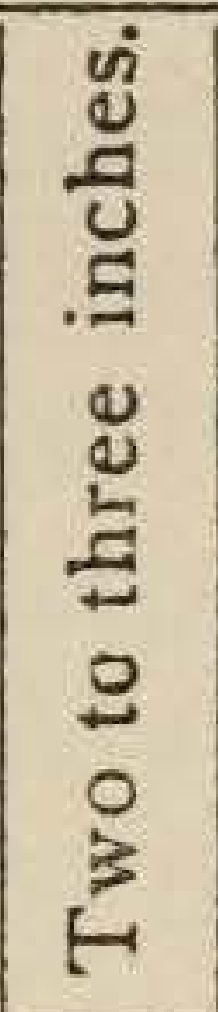 & $\frac{\frac{0}{3}}{\stackrel{0}{0}}$ \\
\hline Number of specimens examined & 3 & 3 & 2 & 4 & 2 & 4 & 4 & 6 \\
\hline I. Fishes ... & & & & 15 & & & & 47 \\
\hline II. INSECTS $\ldots \ldots \ldots \ldots$ & 39 & 99 & 97 & 52 & . & 57 & 64 & 53 \\
\hline Undetermined larvæ......... & $\ldots$ & 16 & $\ldots$ & OI & ... & $\ldots .$. & $\ldots$ & $\ldots$ \\
\hline Caterpillars $\ldots \ldots \ldots \ldots \ldots \ldots$ & $\ldots$ & 17 & $\ldots$ & & ... & $\ldots$ & $\ldots$ & $\ldots$ \\
\hline I. Diptera (larvæ) ............. & 05 & 03 & ... & 06 & ... & 32 & 04 & $\cdots$ \\
\hline Chironomus.............. & 05 & 03 & & & & 26 & 04 & .... \\
\hline 2. Coleoptera $\ldots \ldots \ldots \ldots \ldots \ldots$ & $\ldots$. & $\ldots$ & 02 & 03 & $\ldots$ & $\ldots$. & $\ldots$ & 10 \\
\hline Terrestrial & & $\ldots$. & or & & & .... & & 10 \\
\hline Aquatic .... & . & .... & or & 03 & ... & $\ldots$ & $\ldots$ & .... \\
\hline Dytiscid $x$ & & $\ldots$ & OI & OI & $\ldots$ & .... & $\ldots$ & ... \\
\hline Hydrophilidæ........... & & & $\cdots$ & 02 & & .... & $\ldots$ & \\
\hline 3. Hemiptera............ & . & 63 & 95 & ... & .. & $\cdots$ & 20 & 18 \\
\hline Corixa...$\ldots \ldots \ldots$ & & 63 & 90 & & & .... & 20 & 18 \\
\hline Hygrotrechus (young)..... & $\cdots$ & .... & 05 & & $\cdots$ & $\cdots$ & ... & ... \\
\hline 4. Neuroptera (larvæ)......... & 34 & .... & .... & 42 & & 25 & 40 & 25 \\
\hline Ephemeridæ........... & & & & $2 \mathrm{I}$ & & 03 & 12 & 25 \\
\hline Palingenia ............... & & & & & & .... & ... & 25 \\
\hline Baetis ................ & & ... & .. & OI & ... & .... & & ... \\
\hline Agrionidæ... & & & & OI & & I0 & 28 & .... \\
\hline Libellulidæ. . . . . & & & & 05 & & $\ldots$ & $\ldots$ & $\cdots$ \\
\hline Phryganeidæ ............. & & & & 15 & & ... & $\ldots$ & $\ldots$. \\
\hline III: ARACHNIDA (Hydrachna) & & & & $\dot{\dagger}$ & & $\ldots$ & … & \\
\hline IV. Crustacea $\ldots \ldots \ldots \ldots$ & $6 I$ & ... & $\mathrm{O} 3$ & $3 \mathrm{I}$ & 100 & 43 & 34 & $\dagger$ \\
\hline Decapoda (Cambarus)...... & $\ldots$ & & & $3 I$ & & & & .... \\
\hline Amphipoda ........... & & & 03 & & & ... & & $\ldots$ \\
\hline Entomostraca ............. & $6 \mathrm{I}$ & OI & ... & $\cdots$ & 100 & 43 & 34 & t \\
\hline Cladocera .............. & 58 & & & & 70 & 24 & 34 & $\dagger$ \\
\hline Daphnia ....... & & & & & & $\ldots$ & 21 & $\ldots$ \\
\hline Bosmina ........ & ... & ... & . . & & 70 & & … & $\cdots$ \\
\hline Pleuroxus......... & 33 & & & .. & & $\dagger$ & $\cdots$ & $\cdots+$ \\
\hline Chydorus . . . . . . . . . & & OI & & & 30 & in & $\ldots$ & $\ldots$ \\
\hline $\begin{array}{c}\text { Copepoda } \ldots \ldots \ldots \ldots \ldots \\
\text { V. VEgEtation }\end{array}$ & O3 & $\ldots$ & & $\mathrm{O} 2$ & 30 & .... & $\ddot{0} 2$ & $\cdots$ \\
\hline Potamogeton $\ldots \ldots \ldots \ldots \ldots \ldots$ & $\cdots$ & & & 02 & & & $\ldots$ & $\cdots \cdots$ \\
\hline Algæ $\ldots \ldots \ldots \ldots \ldots \ldots \ldots$ & & & & & & & 02 & ... \\
\hline
\end{tabular}

Apomotis cyanellus, Raf. Blue-spotted Sunfish.

This species, distributed throughout the State, is especially abundant in central Illinois, where it is the common fish of the ponds and smaller streams-." the sun- 
fish" of the country schoolboy and the picnic party. It is the constant companion of the "bull-head" (Amiurus) and "shiner" (Notemigonus) in the small stagnant ponds of the prairie regions, and of the "chub minnow", (Semotilus) in muddy creeks. It was found abundant with Centrarchus, Aphredoderus and Amiurus catus, in the rapidly drying mud-holes, ${ }^{*}$ only a few feet across, left by the retreating overflow of the Mississippi bottoms, in Union county.

\section{Food of the Young.}

The smallest of nineteen specimens studied, was one inch in length-taken in July, in a prairie pond near Normal. Ninety-five per cent. of its food was Cyclops and three per cent. Daphnids. The trifling remainder consisted of a Corixa just hatched, and a Chironomus larvæ.

Nine specimens, ranging from one to two and a fourth inches in length, vary so little in food that it is not worth while to treat them separately. These were taken from various ponds, streams and lakes in central Illinois. Their food was distributed quite generally through the various orders of insects and crustaceans accessible to them, showing the indifferent appetite of this fish and the general effectiveness of its collecting apparatus.

Larvæ of Chironomus, Dytiscidæ, Staphylinidæ, Corixas, Ephemerid larvæ, Decapoda, Isopoda, Cladocera, Cyprids and Copepoda were all found in considerable quantities in the food of these specimens. As usual, the most important insects were Corixas and May-flies-sixteen per cent. of the former and twenty-nine per cent. of the latter. About eight per cent. of the food was Cladocera (Daphnia, Simocephalus, Pleuroxus, Chydorus).

$$
\text { Food of the Adult. }
$$

The eight adults, from northern and southern Illinois, differed from the young in the disappearance of En-

*All the specimens taken from these holes, so muddy that the water was almosi opaque, were of a peculiarly bleached appearance-many of them almost colorless--a fact of interest relative to the laws of coloration among fishes. 
tomostraca from the food, the larger size of the insects taken, and the appearance of fishes and crawfishes.

Among the insects were a large Hydrophilus unknown to me, but nearly as large as $H$. triangularis, the larva of Corydalus cornutus, of Libellula and of some Ephemerid. The fishes composed about thirty-six per cent. of the food. The only recognizable specimens were a small Cyprinoid and a young buffalo-fish (Ichthyobus bubalus). Crawfishes and the river shrimp (Palæmonetes) had been eaten by two of the specimens.

Lepiopomus pallidus, Mit. Common Sunfish.

This abundant, hardy and voracious species, is found throughout the State, and may be regarded as the typical sunfish. It is most plentiful in the larger rivers in central Illinois, being replaced in ponds by Apomotis cyanellus.

Consistently with its wide range and varied habitat, it is a general feeder for a sunfish-peculiar only in the fact of its strictly non-predaceous character. Of fortyfive specimens examined, only one had eaten a fish, and that one only a single small darter.

Undifferentiated Centrarchidae.-I introduce here the food of six specimens of this family which were too small for determination. They were too deep for Micropterus, and as they had but three anal spines, could not have been Ambloplites or Pomoxys. They were probably Lepiopomus pallidus. All were taken from the Illinois River - a part of them near La Salle, in July, 1879 - the others from Peoria, in June, 1878.

The smallest (seven-sixteenths of an inch long) had eaten only Daphniidx. The next in size (one-half inch) contained Cyclops (ninety-eight per cent.) and Chydorus. Nearly the whole of the food of the remaining four was Daphniidæ (ninety-four per cent.), including Daphnia pulex.

\section{Food of the Young.}

My smallest specimens, five in number, ranging 'from three-fourths of an inch to one inch, were taken in Au- 
gust, September and October, at Pekin, Peoria, and Mackinaw Creek, Woodford county. Neither locality nor date seems to have made any marked difference in their food, the principal elements of which were Entomostraca and Chironomus larvæ- fifty-seven per cent. and thirty-seven per cent. respectively.

A few water-spiders (Hydrachnidæ) and undetermined Amphipoda were the other items. The Entomostraca were all Cyclops (twenty per cent.) and Cladocera (Simocephalus vetulus and americanus, Bosmina longirostris and Pleuroxus dentatus).

Nine specimens, between two and three inches long, were caught at the same times and places as the preceding, except that one specimen from Mackinaw Creek was taken in June, and one taken in September was from Clear Lake, Kentucky. The greater size of these specimens was indicated by the appearance of a few Neuroptera larvæ in the food-eight per cent. In other essential respects, the food was like that of the foregoing group. One specimen had eaten largely of water-mites and another of Cyprids (fifty per cent.), and these elements have therefore greater prominence in the averages. Chironomus larvæ and Entomostraca now sum up eightyone per cent.

In the third group of the young, consisting of seven fishes, between two and three inches long, the Chironomus larvæ remain about as before (thirty per cent.), Corixas appear (twenty-five per cent.) and Neuroptera larvæ rise to fourteen per cent. Entomostraca now fall away to a trifle, and larger percentages of Amphipoda appear. Single fishes had eaten the larvæ of a Gyrinid beetle, portions of the Polyzoan Pectinatella magnifica, ${ }^{*}$ Leidy, and an earthworm - the latter probably nibbled from some fisherman's hook.

" This animal forms the large, translucent masses found in midsummer in the slow water along the margins of the Illinois River and elsewhere throughout the state, usually collected about a stick or a stem of a waterweed. They vary from the size of a walnut to that of half a bushel The fragments were easily recognized by the peculiar form and armature of the winter eggs (statoblasts), which are discoidal and bordered with a row of slender double hooks, shaped something like an anchor. 
These specimens were all from the Illinois River, in June, July, October and November.

\section{Food of the Adult.}

The twenty-four adults examined were from various parts of the State north of the center; and, as the food has been found to differ so widely according to the local situation, I have treated them in three groups-the first including those taken in the clear, inland, northern lakes; the second those from Calumet River, at South Chicago, and the shallow, muddy lakes of that vicinity, and the third those from the Illinois River from Ottawa to Peoria.

The specimens from the northern lakes were taken in May and June. Sixty-two per cent. of the food consisted of Neuroptera-eight per cent. being a black caddis-fly (Sialis infumata) and the remainder the larvæ of large dragon-flies (Libellulidx), Agrions (eleven per cent.) and Baëtis (two per cent.). Allorchestes dentata was the next most important element (twenty-seven per-cent.). A number of terrestrial insects besides Sialis appeared in the food. These included a Harpalid beetle, an Aphodius fimetarius, and some grasshoppers (Tettigidæ, ete.).

The second group of four, from Calumet River, and from Lake George, Indiana, was peculiar in the number of tetradecapod Crustacea and case-worms taken, and especially in the amount of vegetation eaten.

The Crustacea were Allorchestes (thirty-two per cent.) and Asellus (twenty per cent.). The vegetation was present in such quantities as to make it evident that it had been taken as food. It amounted to about a fourth of the contents of these stomachs. The stomach of one fish was packed with a piece of the stem of a plant (apparently a Scirpus) a third of an inch in diameter and six inches long. Three others contained smaller amounts of confervoid Algæ.

The fifteen specimens remaining were taken from the Illinois in May, July, August, October and November. Their food was especially noticeable for the presence of 
mollusks (sixteen per cent.), for the number and variety of land insects (fifteen per cent.), and for the large amount of vegetation it contained (thirty-one per cent.). A single small fish-the only one taken by these fortyfive specimens-was also noticed.

The mollusks included Planorbis, Physa, Amnicola and Vivipara. Among the insects were ants, caterpillars, flies, Anisodactylus discoideus and other Harpalids, Aphodius inquinatus, wire-worms, minute curculios, Cryptocephalus 4-maculatus, Diabrotica 12-guttata, Colorado potato beetles, flea-beetles, plant-bugs (Pentatomidæ), crickets (Nemobius), locusts, katydids (Phaneroptera curvicauda), grasshoppers and case-flies.

The vegetable food, as far as determined, consisted of Ceratophyllum, Nais flexilis and confervoid Algæ. Fragments of Polyzoa were noticed. Coptotomus interrogatus, Gyrinid larvæ, Tropisternus limbatus and other Hydrophilidæ, larval and adult, a large Nepa, larvæ of Palingenia bilineata and other May-flies, of Agrions and dragon-flies were among the aquatic insects taken.

The Crustacea were limited to small crawfishes (two per cent.), a trace of Allorchestes, and a few Aselli (four per cent.).

On comparing specimens from northern Illinois with those taken from the Illinois River in the same month, I find that there are no common seasonal food characters, and that the differences of food are therefore due to difference of locality and not to difference of time represented by the groups. Concerning the entire number of adults, we can therefore say that their food ranges through the whole list of the smaller mollusks, terrestrial and aquatic insects, and smaller crustaceans (above Entomostraca) accessible in their localities, and that they feed largely on aquatic vegetation. A striking negative feature is the almost total absence of fishes in the fooda fact which corresponds with the relatively small size of the mouth.

\footnotetext{
* Several of these little-known larvæ were found in the stomachs of this species,- some of them in suitable condition for description.
} 
Table of Food of Apomotis and Lepiopomus.

\begin{tabular}{|c|c|c|c|c|c|c|c|c|c|c|}
\hline & \multicolumn{3}{|c|}{ APOMOTIS. } & \multicolumn{6}{|c|}{ LEPIOPOMUS. } & \\
\hline & 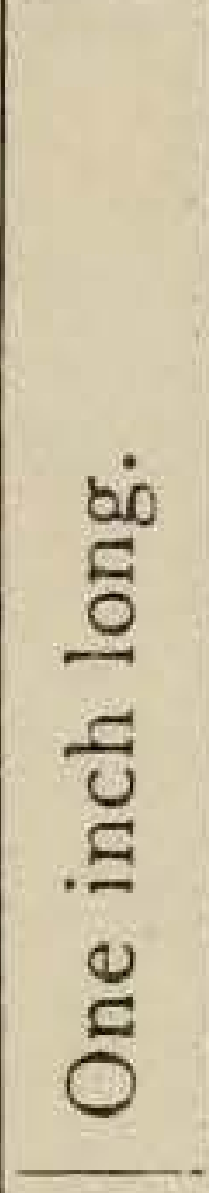 & 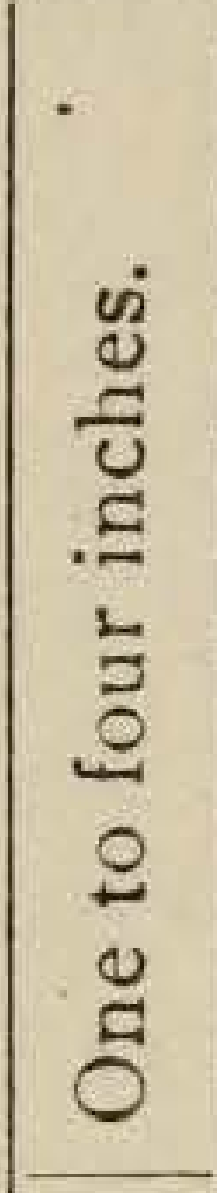 & $\frac{\dot{m}}{\frac{0}{2}}$ & 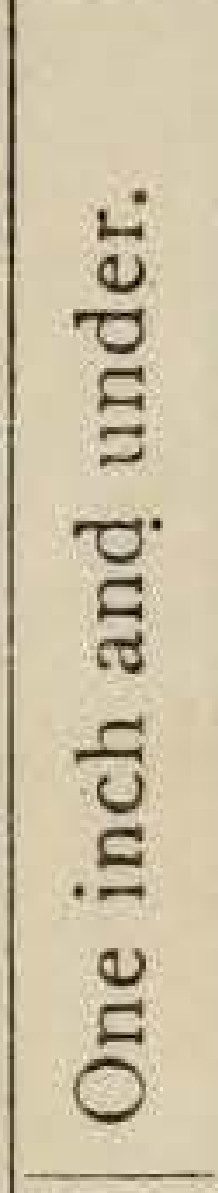 & 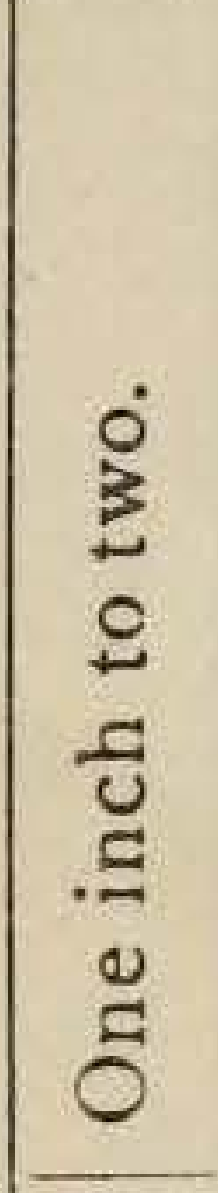 & 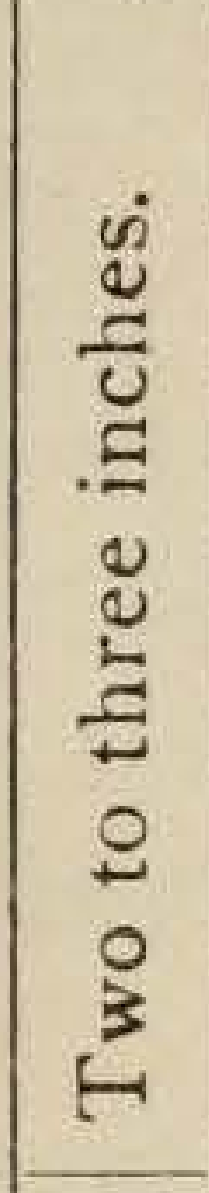 & 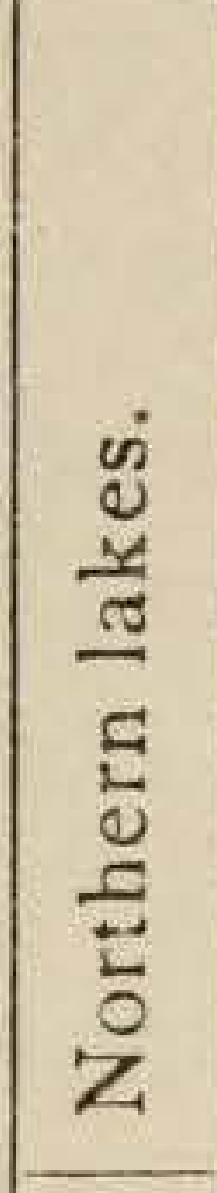 & 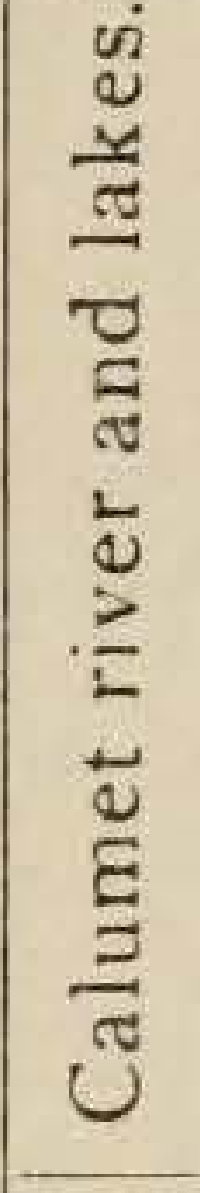 & $\begin{array}{l}\bar{c} \\
\frac{2}{L} \\
\frac{n}{0} \\
\Xi \\
\Xi\end{array}$ & $\frac{\stackrel{\dot{v}}{3}}{3}$ \\
\hline $\begin{array}{l}\text { Number of specimens.. } \\
\text { I. FISHES . . . . . }\end{array}$ & I & 10 & 8 & 5 & 9 & 7 & 5 & 4 & 15 & 24 \\
\hline Undetermi & $\cdots$ & $\cdots$ & $\begin{array}{l}30 \\
10\end{array}$ & & & $\begin{array}{l}\cdots \\
\cdots\end{array}$ & $\cdots$ & & $\begin{array}{l}\text { IO } \\
\cdots\end{array}$ & OI \\
\hline $\begin{array}{l}\text { Etheostoma } \\
\text { Cyprinidæ . }\end{array}$ & $\cdots$ & . $\cdots$ & $\cdots$ & & .. & ... & $\therefore$ & $\ldots$ & OI & \\
\hline $\begin{array}{l}\text { Cyprinidæ. } \\
\text { Ichthyobus. }\end{array}$ & $\cdots$ & $\cdots$ & 13 & & . & $\cdots$ & $\cdots$ & $\cdots$ & ... & ... \\
\hline $\begin{array}{l}\text { Ichthyobus } \\
\text { II. MoLI }\end{array}$ & $\cdots$ & $\cdots$ & 13 & & & $\because$ & $\cdots$ & $\cdots$ & $\cdots$ & $\cdots$ \\
\hline I. Gasteropoda & $\ldots$ & $\cdots$ & $\ldots$ & & . & $\cdots$ & $\begin{array}{l}\cdots \\
\cdots\end{array}$ & & $\begin{array}{l}10 \\
10\end{array}$ & $\begin{array}{l}\text { I0 } \\
\text { I0 }\end{array}$ \\
\hline Undetermined ........ & $\cdots$ & $\cdots$ & & & & ... & ... & .. & 04 & 20 \\
\hline Planorbis .... & $\cdots$ & $\cdots$ & & & & ... & $\cdots$ & & t & \\
\hline Physa........ & $\cdots$ & $\cdots$ & $\cdots$ & $\cdots$ & & $\cdots$ & $\cdots$ & & 05 & \\
\hline Vivip & & $\cdots$ & $\cdots$ & & & . & $\cdots$ & + & C7 & \\
\hline $\begin{array}{l}\text { Amnicola... } \\
\text { 2. Acephala... }\end{array}$ & & $\cdots$ & $\cdots$ & & 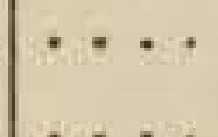 & $\cdots$ & $\cdots$ & $\cdots$ & t & $\dagger$ \\
\hline $\begin{array}{l}\text { 2. Acephala..... . } \\
\text { III. Insecta... }\end{array}$ & $\dddot{\mathrm{O}} 2$ & 79 & 42 & 37 & 34 & 72 & & $\cdots$ & & \\
\hline Undetermined $\ldots \ldots \ldots$ & $\ldots$ & 12 & or & & $\ldots$ & $\mathrm{O} 2$ & $\begin{array}{l}70 \\
\ldots\end{array}$ & $\begin{array}{l}23 \\
\ldots \ldots\end{array}$ & $\begin{array}{l}43 \\
\ldots\end{array}$ & 45 \\
\hline Terrestrial $\ldots \ldots \ldots \ldots$ & $\ldots$ & 07 & .... & & ... & … & 05 & OI & 15 & 12 \\
\hline Aquatic $\ldots \ldots \ldots \ldots$ & 02 & 60 & $4 \mathrm{I}$ & 37 & 34 & 70 & 05 & 22 & 28 & 33 \\
\hline 1. Diptera(Chironomus) & OI & 09 & $\cdots$ & 37 & 26 & 30 & & + & OI & OI \\
\hline 2. Coleoptera........... & $\cdots$ & 02 & 05 & & $\because \cdots$ & OI & OI & OI & 09 & 06 \\
\hline Undetermined. & $\ldots$ & $\ldots$ & $\ldots$. & & & .. & $\cdots$ & + & 04 & \\
\hline Dytiscidæ..... & $\cdots$ & 02 & & & & & $\cdots$ & .... & 02 & \\
\hline Undetermine & $\cdots$ & 02 & $\cdots$ & & $\cdots$ & . & $\cdots$ & $\cdots$ & $\cdots$ & \\
\hline Lar & $\cdots$ & $\cdots$ & $\cdots$ & & ․ & $\cdots$ & $\cdots$ & $\cdots$ & OI & \\
\hline Cop & $\cdots$ & ... & $\cdots$ & & . & .. & $\cdots$ & $\cdots$ & OI & \\
\hline Gyrinidæ & $\cdots$ & $\cdots$ & & & . & 01 & $\cdots$ & OI & OI & \\
\hline Hydr & $\cdots$ & ... & .... & & .. & $\cdots$ & OI & ... & $\mathrm{O} 2$ & \\
\hline Undetermined. & . & & 05 & & & & $\cdots$ & & OI & \\
\hline Trol & $\cdots$ & & $\cdots$. & & & $\cdots$ & … & $\cdots \cdot$ & OI & \\
\hline 3. Hemiptera.......... & OI & I6 & 03 & t & & 25 & 02 & OI & 04 & 02 \\
\hline Undetermined ......... & $\ldots$ & $\cdots$ & $\ldots$ & & $\cdots$ & $\ldots$ & $\cdots$ & .... & ... & \\
\hline Corixa $\ldots \ldots \ldots \ldots \ldots$ & ol & 16 & 03 & & & 25 & OI & & 04 & \\
\hline Nep & $\cdots$ & $\cdots$ & $\cdots$ & & $\cdots$ & $\cdots$ & 01 & & $\cdots$ & \\
\hline $\begin{array}{r}\operatorname{Ran} \\
\text { 4. } N e r\end{array}$ & & 33 & 33 & & os & 14 & 62 & 20 & I4 & 24 \\
\hline Larv & & $\cdots$ & & & OI & $\ldots$ & $\ldots$ & ... & & \\
\hline meridæ (larvæ).... & & 29 & 27 & & 07 & .. & 02 & & 05 & 03 \\
\hline & ... & $\cdots$ & $\cdots$ & & $\ldots$ & $\cdots$ & $\mathrm{O} 2$ & & & \\
\hline & & & OI & & $\ldots$ & $\cdots$ & ... & $\ldots$ & 04 & 02 \\
\hline Agrionidæ (larvæ). & $\ldots$ & $\cdots$ & 06 & & $\cdots$ & 14 & II & $\ldots \therefore$ & $\dagger$ & 10 \\
\hline & & 04 & & & & & $4 \mathrm{I}$ & & O2 & \\
\hline
\end{tabular}


Table of Food of Apomotis and Lepiopomus-Continued.

\begin{tabular}{|c|c|c|c|c|c|c|c|c|c|c|}
\hline & AP & омо: & TIS. & & & EPI & $\mathrm{OM}$ & & & \\
\hline - & 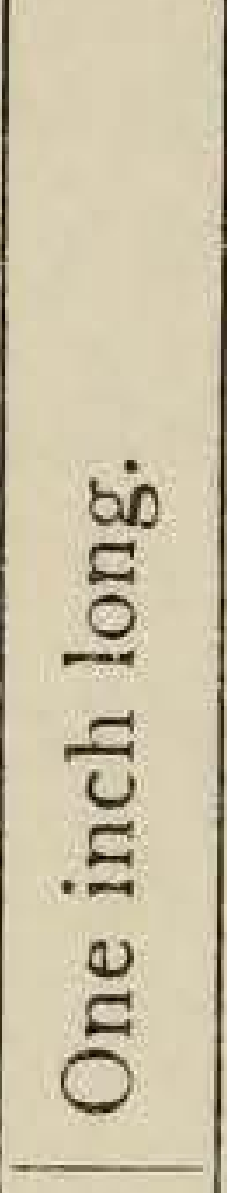 & 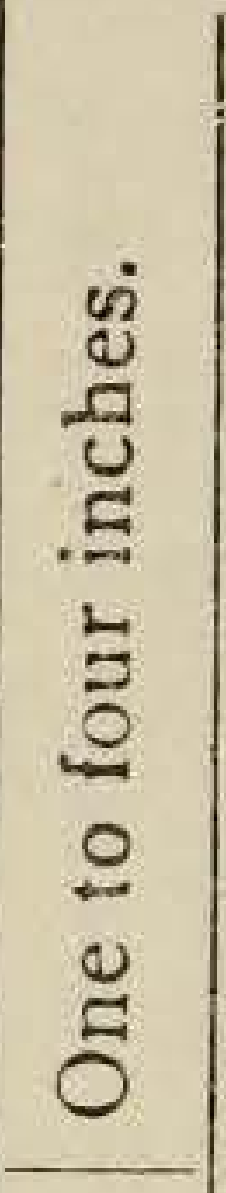 & $\frac{\dot{\dot{g}}}{\frac{\tilde{J}}{Z}}$ & 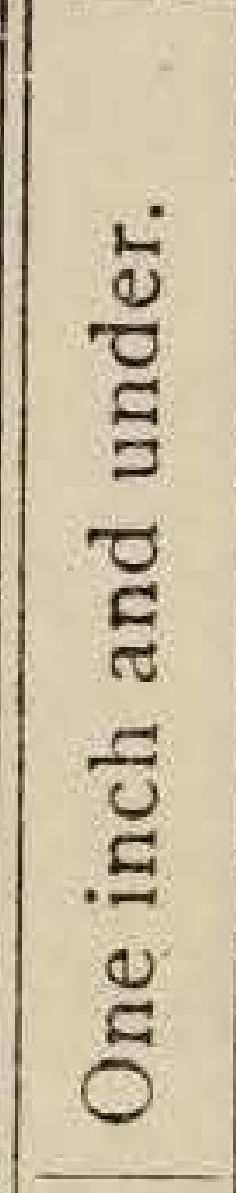 & 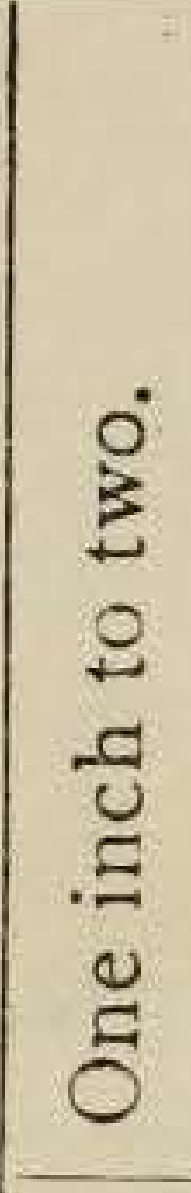 & 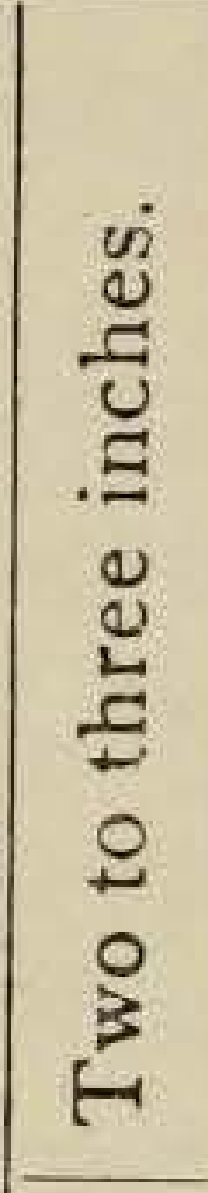 & 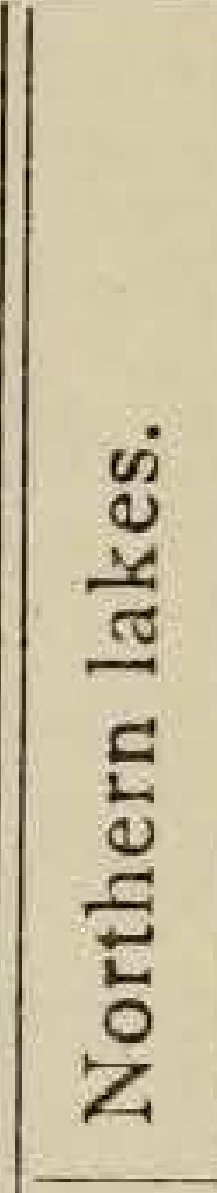 & 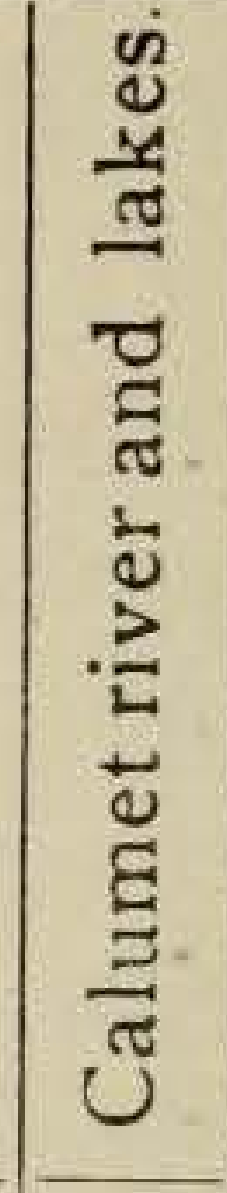 & 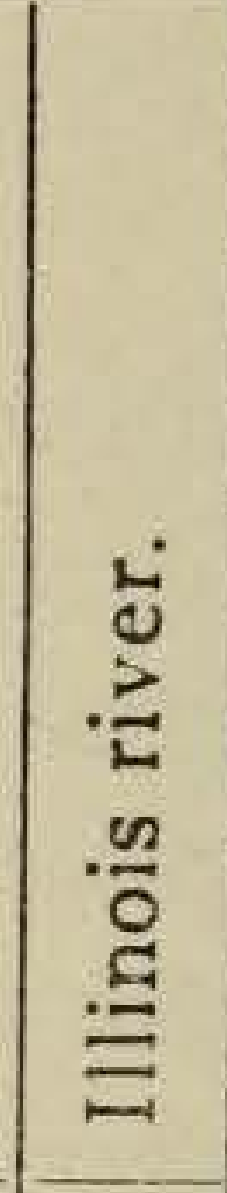 & 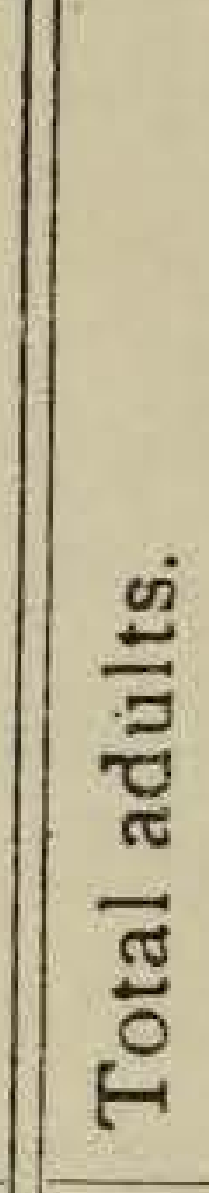 \\
\hline Number of specimens.. & I & Io & 8 & 5 & 9 & 7 & 5 & 4 & I5 & 24 \\
\hline Sialidæ . ............. & $\cdots \cdots$ & $\cdots$ & 04 & & ... & & 08 & ... & 07 & 06 \\
\hline$\underset{\text { Corydalus (larvæe }}{\text { Sialis }}$ & $\cdots$ & $\cdots$ & ... & $\cdots$ & ... & $\ldots$ & 08 & $\cdots$ & 07 & 06 \\
\hline $\begin{array}{l}\text { Corydalus (larvæ)... } \\
\text { Phruganeidæ }\end{array}$ & $\cdots$ & $\cdots$ & 04 & .... & .... & $\cdots$ & $\cdots$ & $\cdots$ & $\cdots$ & ... \\
\hline $\begin{array}{l}\text { Phryganeidæ........... } \\
\text { IV. ARACHNIDA..... }\end{array}$ & $\cdots$ & $\cdots$ & $\cdots$ & $\begin{array}{l}\cdots \\
0_{4}\end{array}$ & II & oi & OI & 20 & $\cdots$ & $\mathrm{O} 3$ \\
\hline Spiders. ........... & $\ldots$ & $\cdots$ & $\ldots$ & .... & $\ldots$ & .... & OI & + & & $\cdots$ \\
\hline Hydrachnidæ . ......... & & $\ldots$ & ... & 04 & II & oI & & & $\dagger$ & $\cdots$ \\
\hline V. CRustacea $\ldots$... & 98 & 21 & 20 & 59 & 55 & 06 & 27 & 52 & 06 & 18 \\
\hline Decapoda. & $\cdots$ & OI & 20 & $\ldots$ & $\cdots$ & . $\cdots$ & ... & ... & $\mathrm{O} 2$ & OI \\
\hline Undetermined....... & $\cdots$ & OI & 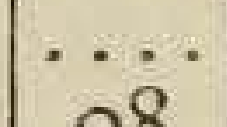 & $\cdots$ & $\cdots$ & $\cdots$ & $\cdots$ & $\cdots$ & $\cdots$ & ... \\
\hline $\begin{array}{l}\text { Cambarus } \\
\text { Palæmon }\end{array}$ & $\cdots$ & $\cdots$ & $\begin{array}{l}08 \\
12\end{array}$ & & $\cdots$ & $\ldots$ & $\cdots$ & & 02 & $\cdots$ \\
\hline $\begin{array}{l}\text { Palæmon } \\
\text { Amphipoda }\end{array}$ & & $\cdots$ & $\ldots$ & $\mathrm{O} 2$ & & 05 & 27 & 32 & $\cdots \cdot$ & II \\
\hline Undetermined....... & & ... & $\ldots$ & $\mathrm{O} 2$ & & .... & $\ldots$ & & & \\
\hline Allor & $\ldots$ & ... & .. & ... & $\cdots$ & 05 & 27 & 32 & $\dagger$ & .... \\
\hline Isopoda (Asellus) ...... & & 04 & & 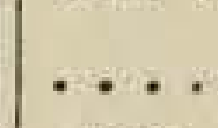 & & $\ldots$ & -1 & 20 & 04 & 06 \\
\hline Entomostraca .......... & 98 & 16 & ... & 57 & 55 & OI & & $t$ & .... & .... \\
\hline Cladoce & $\ldots$ & -08 & .. & 37 & I4 & $\cdots$ & $\ldots$ & $\dagger$ & $\cdots$ & ... \\
\hline Daphniidæ........ & 03 & 07 & & 33 & 12 & & $\cdots$ & & $\cdots$ & $\cdots$ \\
\hline ceidæ .......... & $\ldots$ & OI & & 04 & $\mathrm{O} 2$ & OI & & $t$ & & ... \\
\hline Ostracoda ............ & $\ldots$ & 03 & ... & $\ldots$ & 06 & & $\cdots$ & $\dagger$ & $\dagger$ & ... \\
\hline Copepoda. ......... & 95 & 05 & $\cdots$ & 20 & 35 & $\dagger$ & $\cdots$ & $\cdots$ & & \\
\hline $\begin{array}{l}\text { VI. VERMES } \\
\text { VE. } \ldots\end{array}$ & & $\cdots$ & $\cdots$ & .. & $\cdots$ & 20 & & & $\mathrm{O} 3$ & $\mathrm{O} 2$ \\
\hline $\begin{array}{l}\text { Undetermir } \\
\text { Polyrea }\end{array}$ & & & & & & ${ }_{11}^{\dagger}$ & & $\ldots$. & $\mathrm{O} 3$ & $\mathrm{O}_{\mathrm{O} 2}$ \\
\hline $\begin{array}{l}\text { Polyzoa . } \\
\text { Lumbricu }\end{array}$ & & & $\cdots$ & . & & O9 & … $>$ & $\ldots$. & .... & $\cdots$ \\
\hline VEGETATION. . & & & 02 & & & or & 02 & 25 & $3 I$ & 24 \\
\hline sempusc & & $\ldots$ & $\mathrm{O} 2$ & ... & .. & OI & $\mathrm{O} 2$ & 21 & I9 & 16 \\
\hline $\lg { }^{\prime} \ldots \ldots \ldots \ldots \ldots$ & ...... & $\cdots \cdot$ & ....... & $\ldots$ & .... $>$ & $1 . .$. & $1 \ldots .$. & 04 & 12 & 08 \\
\hline
\end{tabular}

Xenotis megalotis, Raf. Long-eared Sunfish.

This little species is not at all common in the State, but has been taken by us from the middle course of Fox R., from tributaries of the Illinois R., and from ponds in Union county and southern Iliinois.

Unfortunately, the three specimens examined had not lately taken food, and only a very imperfect notion of their usual aliment can be given. Corixa, Ephemerid 
larvæ, Chironomus larvæ, the tube of a case-worm, a few fish-scales and an indeterminable aquatic beetle were the only objects found.

\section{Xenotis peltastes, Cope.*}

This beautiful little fish, hitherto taken in this State only in very small number from Fox R., was found quite abundant in the "slip" at South Chicago, in June, 1880. The three opened had eaten more larvæ of Chironomus than anything else (sixty per cent.). Next came sixteen per cent. of mollusks, then Allorehestes and Asellus, Corixa, Gyrinid larvæ and a few terrestrial larvæ (Chrysomelidæ). The large percentage of Chironomus was probably owing to the situation-a foul and muddy little bay, serving as a harbor for fishing boats.

Eupomotis aureus, Wahl. Pumpkin-seed. Bream.

This species swarms in the lakes and ponds of northeastern Illinois, but is much less abundant in the Illinois R., and in the southern part of the State is almost unknown. The cause of this limitation of its range is apparently climatic, as there is certainly nothing in its food, nor, apparently, in any of its habits, to exclude it from our southern waters. Indeed, I do not see that its place is taken by any other fish to the southward. No other, unless Eupomotis pallidus, resembles it in food, and this is too infrequent to replace it. My knowledge of its food is based upon the study of twenty-five specimens ranging from one and one-half inches upward, taken from the Illinois, Fox and Calumet rivers, and from Long, Crystal and Nipisink lakes and Lake George, in central and northern Illinois and Indiana. The months of May, June, July, August and October are represented by these specimens.

\section{Food of the Young.}

The nine smaller specimens, from one and one-half to two inches long, show at once two prominent peculiarities of the food. The larvæ of Chironomus compose fifty-one

* It is considered doubtful, by Dr. Jordan, if this species and the preceding are distinct. 
per cent. of the food, and Entomostraca of the order Ostracoda (Cyprids), twenty-six. As both these are found most abundantly in muddy bottoms, it is evident that the fish is, at least at first, a bottom feeder. Traces of mollusks appear thus early, as well as a few Ephemerid larvæ (five per cent.). The remainder of the food was insects' eggs and Daphnids-chiefly Simocephalus americanus-(twelve per cent.). Chydorus was found in five specimens, but in too small quantity to figure in the averages.

Five specimens were studied between two and three inches long. In these the same food characters continue, modified somewhat by the introduction of larger objects. The Chironomus larvæ stand at forty-four per cent., and the Cyprids at eighteen per cent. Fourteen per cent. of Allorchestes and eleven per cent. of Neuroptera larvæ are the only important elements remaining. Two per cent. of young Unios were noticed. Nearly half of the food of two larger specimens, between two and three inches long, consisted of mollusks-chiefly Physa. A few Chironomi and about equal quantities of Ephemerid larvæ and Allorchestes were all the remaining food. Entomostraca therefore disappear at this point.

\section{Food of the Adult.}

Forty-six per cent. of the food of the nine adults consisted of Mollusca, including Planorbis, Amnicola and Valvata tricarinata, and six per cent. of undetermined bivalves.

The insect food was twenty per cent. of the whole. Crustacea twenty-two per cent., and vegetation twelve per cent. Half of the last was Chara, and the remainder chiefly Myriophyllum and Algx. The Crustacea were all Allorchestes and Asellus. The insects included a trace of Chironomus larvæ and a few water-beetles (Hydrophilidæ), and the usual Neuroptera larvæ, among which caseflies of the genus Leptocerus were noticed.

Not a trace of fishes was found in the stomachs of these specimens; and this fact, together with the large percentage of molluscan food, constituted the leading alimentary peculiarities of the species. 
The first of these is doubtless related to the small moutl! - the second to the stout, blunt pharyngeal teeth-a character used in defining the genus. In all the preceding species the pharyngeals are set with more slender, pointed teeth.

Eupomotis pallidus, Ag. Pale Sunfish.

Having but few specimens of this rather uncommon species, I have examined the food of but one-enough to indicate that it probably agrees closely with the preceding species.

This fish, taken in Clear Lake, Ky., had eaten largely of small Mollusca-young Unionidæ, Planorbis, Amnicola, etc. These amounted to seventy-five per cent. of the food. 'The remaining elements were Chironomus larvæ, several small water-beetles, (Hydroporus hybridus, Cnemidotus 12-punctatus, and Haliplus, sp.), an unknown aquatic pupa and a little pond-weed.

Centrarchus irideus, Lac.

This little species is found in considerable numbers in ponds and streams in the southern hill-country of Illinois. My specimens, all taken in July, are from ponds and streams in the Mississippi bottoms in Union and Jackson counties, and from Cache R. and its tributaries in Johnson county.

Five of the young, from three-fourths of an inch to an inch in length, had eaten seventy-one per cent. of Entomostraca and twenty-one per cent. of larvæ of Chironomus, and, for the rest, about equal quantities of Ephemerid larvæ and young Allorchestes, with a trace of water mites (Hydrachnidæ).

Thirty-eight per cent. of the food was Cyclops; Cyprids amounted to twenty-one per cent.; and twelve per cent. of Simocephalus completed the ratio of Entomostraca. The smallest specimen, three-fourths of an inch long, had eaten sixty per cent. Simocephalus and forty per cent. Cyclops.

About a fifth of the food of one specimen, an inch and an eighth in length, consisted of minute young Corixas, the remainder being about equally Cyclops and Cyprids. 
Table of Food of Eupomotis and Centrarchus.

\begin{tabular}{|c|c|c|c|c|c|c|c|}
\hline \multirow[t]{2}{*}{ * } & \multicolumn{4}{|c|}{ EUPOмотIS. } & \multicolumn{3}{|c|}{$\begin{array}{c}\text { CEN- } \\
\text { TRARCHUS. }\end{array}$} \\
\hline & 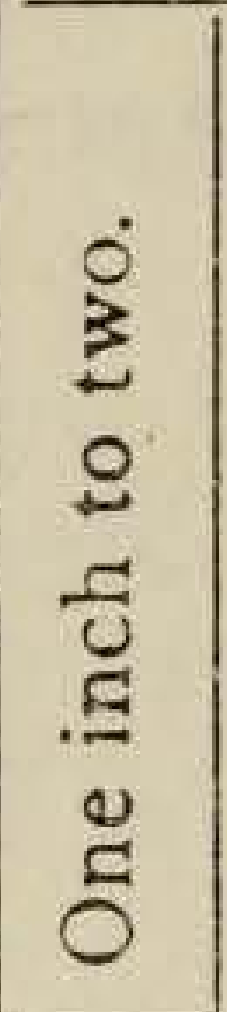 & 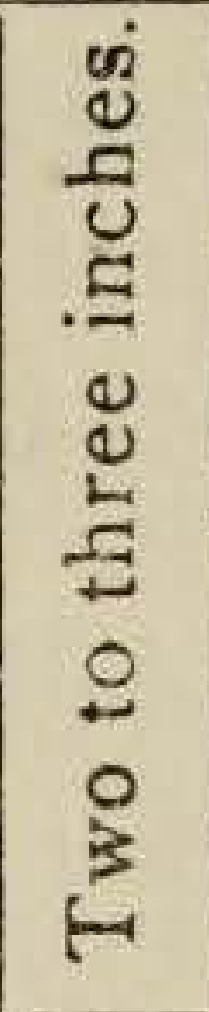 & 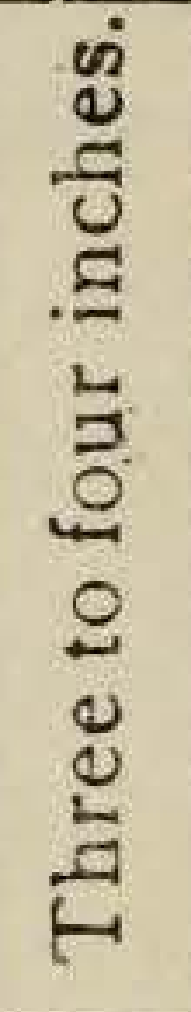 & 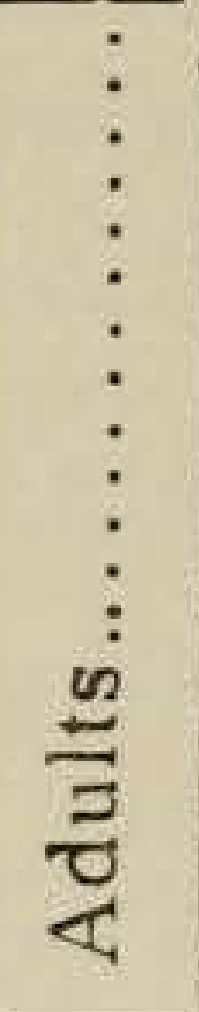 & 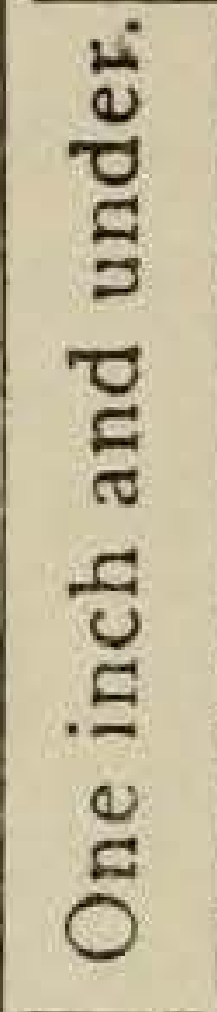 & 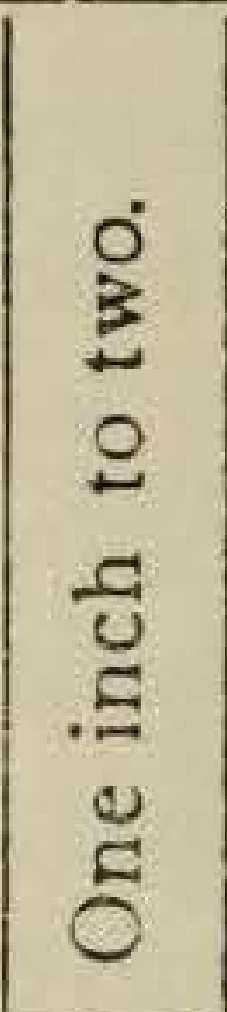 & $\frac{\dot{0}}{\frac{ \pm}{3}}$ \\
\hline Number of specimens examined.... & 9 & 5 & 2 & 9 & 5 & I & 2 \\
\hline 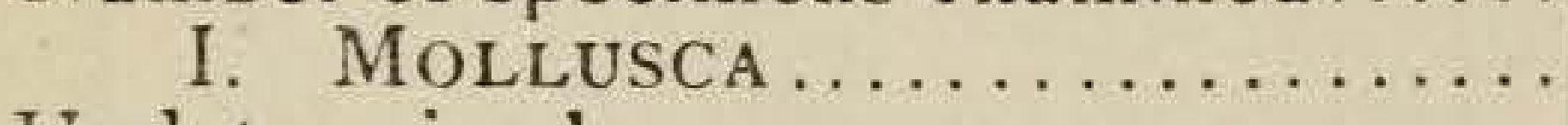 & or & 04 & 45 & 46 & & & \\
\hline Undetermin & $\ldots$ & & & 07 & & & \\
\hline$\ldots \ldots \ldots \ldots$ & OI & $\mathrm{O} 2$ & 45 & 33 & .. & .. & \\
\hline$\ldots \ldots \ldots \ldots \ldots$ & $\cdots$ & $\ldots$ & $\cdots$ & 04 & ... & & \\
\hline Vivip & $\cdots$ & ... & ... & II & & & \\
\hline Plano & & .. & & OI & & & \\
\hline $\begin{array}{l}\text { Physa. } \\
\text { lcephala }\end{array}$ & $\cdots$ & … & 40 & & & & \\
\hline $\begin{array}{l}\text { Acephala } \\
\text { II. INs }\end{array}$ & & 02 & $\cdots$ & 06 & $\cdots$ & & \\
\hline Undeterm & $\begin{array}{l}60 \\
03\end{array}$ & $\begin{array}{l}01 \\
03\end{array}$ & 30 & 20 & 24 & $\begin{array}{l}20 \\
\ldots \ldots\end{array}$ & $\begin{array}{l}91 \\
07\end{array}$ \\
\hline 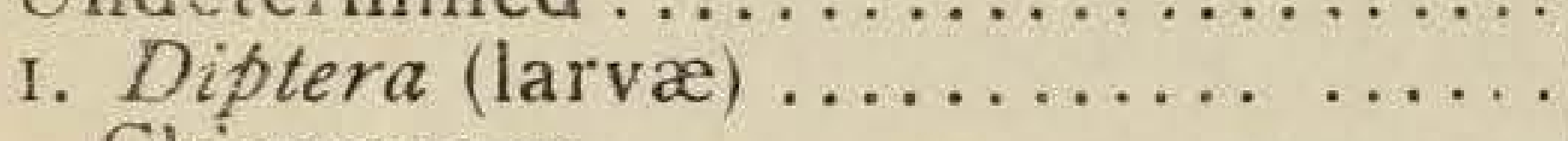 & 52 & 45 & 05 & or & $2 \mathrm{I}$ & $\cdots \cdots$ & of \\
\hline Chironomus $\ldots \ldots \ldots \ldots \ldots \ldots \ldots$ & 51 & 44 & 05 & OI & $2 \mathrm{I}$ & & 06 \\
\hline 2. Coleoptera ...................... & $\ldots$ & 02 & ( & 02 & $\mathrm{x}$ & & ... \\
\hline & & 02 & & 02 & & & $\ldots$ \\
\hline 3. Hemiptera.................... & & S & & & & 20 & 23 \\
\hline Corixa $\ldots \ldots \ldots \ldots \ldots \ldots \ldots$ & & & & & & 20 & 23 \\
\hline Neuroptera (larvæ) ............... & 05 & 11 & 25 & 17 & O3 & & 55 \\
\hline 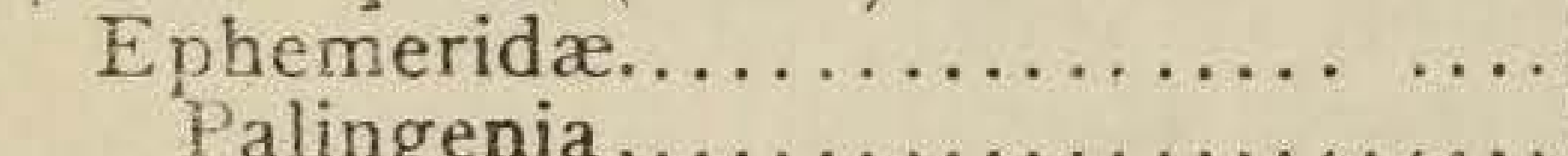 & 05 & 05 & 25 & 03 & 03 & $\cdots$ & 55 \\
\hline $\begin{array}{l}\text { Pali } \\
\text { Agrion }\end{array}$ & & 06 & & 03 & & & \\
\hline & & & & 08 & & & \\
\hline Phryganeidæ..... & & & & 02 & & & ‥ \\
\hline & & & & ... & or & & \\
\hline . $\quad \ldots \ldots \ldots \ldots$ & .. & & & & or & & \\
\hline IV. CRustacea $\ldots \ldots \ldots \ldots \ldots$ & 39 & 35 & 25 & 22 & 75 & 80 & $\cdots$ \\
\hline Amphipoda (Allorchestes)....... & & 14 & 25 & 13 & 04 & $\cdots$ & \\
\hline & & & & 9 & & & \\
\hline$\ldots \ldots \ldots \ldots \ldots$ & 39 & $2 I$ & & & 71 & 80 & \\
\hline & 13 & 03 & & & 12 & & \\
\hline & 12 & $0:$ & & & 12 & & \\
\hline Ost & 26 & 18 & & & $2 \mathrm{I}$ & 35 & \\
\hline $\mathrm{Con}$ & $\cdots$ & & & $\ldots$ & 38 & 45 & $\infty 9$ \\
\hline VEGE & & $\dagger$ & & 12 & $\cdots$ & & $\cdots$ \\
\hline phyllum... & & & & 04 & & & 然 \\
\hline & & $\because$ & & 06 & & & \\
\hline 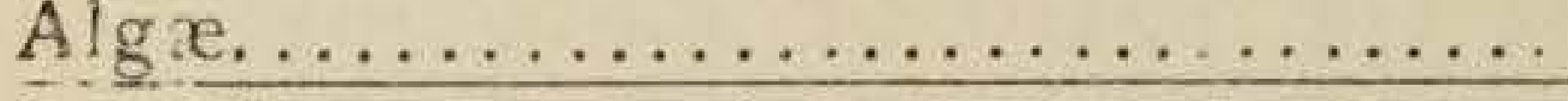 & & \pm & & $\mathrm{O} 2$ & & & \\
\hline
\end{tabular}

Only two specimens were examined which could be classed as adults - one three and a fourth inches long, the other smaller. These indicate that the food of full-grown individuals differs from that of the young chiefly in the 
addition of considerable quantities of terrestrial and aquatic insects.

The gill-rakers of this species are numerous, long and slender - a fact reflected in the food. Fifteen per cent. of the contents of the stomach of the largest specimen consisted of Cyclops and five per cent. of Chironomus larvæ. Consistently with the small mouth and pointed pharyngeal teeth, no traces of fishes or mollusks were found in the food.

Pomoxys nigromaculatus, Lac. Black Croppie. Lake Croppie. Silver Bass. Butter Bass.

Pomoxys annularis, Raf. White Croppie. Timber

Croppie. Silver Bass.

These two species, often not distinguished even by experienced fishermen, agree so closely in food that I have not thought it worth while to treat them separately. In the Illinois and Mississippi rivers they are much the most valuable and important of the family, excepting the black bass. They are nowhere else so abundant in the State, although occurring in the larger rivers generally and in the Great Lakes. The first species is commonest to the north, and the second southward, so far as my observation goes. In the Illinois they are about equally abundant. These fishes are everywhere great favorites, and rank among the most important and promising of our smaller species. They are rarely found in creeks or small ponds, but seem to require deeper water for their maintenance.

The gill-rakers of this species are numerous, long, and finely toothed, constituting the most efficient straining apparatus to be found among the sunfishes. The pharyngeal teeth are sharp, and the mouth is rather wide and considerably enlarged by the lengthening of the lower jaw.

Consistently with the hypothesis concerning the meaning of the gill-rakers which I had already formed from a study of the preceding species, before I came to this, I found that the young continued to feed almost exclusively upon Entomostraca much longer than the other sunfishes. Six specimens between three and four inches long, 
had eaten little else than Entomostraca and the larvæ of minute Diptera (Chironomus Corethra). Even fullgrown specimens were found eating Cladocera more freely than any other food. As might be inferred from the pharyngeals, not a trace of molluscan food was found in the forty-two specimens examined, while fishes formed nine per cent. of the food of the twenty-seven adults. Most of these were eaten late in the season, when Entomostraca and insect larvæ became less abundant.

\section{Food of the Young.}

The smallest specimen, three-fourths of an inch long, had eaten abeut equal quantities of Cyclops and Simocephalus, with only a few Pleuroxus beside. Three, an inch long and under, had confined their food entirely to Entomostraca and Chironomus larvæ- the latter forming about a fourth of the whole. A third of the Entomostraca were Cyclops, the remainder chiefly Simocephalus.

Six specimens between one and three inches long, differed especially in the introduction of about eighteen per cent. of Corixas and three per cent. of small Ephemerid larvæ. Chironomus larvæ were reduced to seven per cent. The Entomostraca were about equally divided between Cyclops and Cladocera. One specimen taken in July, 1879, from the canal near Ottawa, had taken a large number of Daphnella.

Six specimens between three and four inches long were examined. Eighty-three per cent. of their food was Entomostraca, about three-fourths of this amount being $\mathrm{Cy}$ clops, and the remainder nearly all Simocephalus. Twelve per cent. of larvæ of Chironomus and Corethra, three per cent. Corixas and two per cent. larvæ of small Ephemerids were the insect elements. Chydorus, Pleuroxus and Cypris were present in small numbers.

These fifteen young, agreeing so closely in food, irrespective of size, were nevertheless from a variety of situations and dates. All were from the Illinois River, its lakes and tributaries, from Ottawa to Pekin, but ranged in time from June to October of three different years.

Six were $P$. nigromaculatus, seven were $P$. annularis, and two were not identified specifically. 


\section{Food of the Adults.}

An examination of the notes on the twenty-seven adults shows material differences of food at different parts of the year. As all but one were taken from the Illinois River, I have not the means of noting the correspondence of food with locality.

Five specimens taken at Peoria, in March, were found feeding most freely upon Cladocera, which composed fifty-five per cent. of their food. These were chiefly of the two species Simocephalus vetulus and S. americanus. These little Entomostraca were taken at that time in such quantity as visibly to distend the stomach when seen from the outside, and the immense number of their eggs gave a reddish color to the contents of the alimentary canal. The larvæ of Neuroptera, both "darning-needles" and May-flies (Palingenia), were also eaten in considerahle numbers (thirty-nine per cent.). A small Hybopis, a little darter (Boleosoma maculata) and an unrecognizable fish were found in these stomachs, making about six per cent. of the food. Only trivial numbers of Entomostraca appear after this time.

Nine specimens, taken in April, likewise at Peoria, were feeding chiefly upon Neuroptera larvæ (eighty-six per cent.), especially upon that almost invaluable element of fish food, the larva of Palingenia bilineata (sixty-six per cent.). A few larvæ of Gyrinidæ and Dytiscidæ were noted (three per cent.), and a few Corixas also. A Gammarus fasciatus and a little Ceratophyllum, etc.. were noticed; and also the flower of an elm and the feather of a bird.

A single specimen from Pistakee Lake, in McHenry county, taken in May, gave evidence of a similar reliance upon Neuropterous larvæ (eighty-five per cent.). Here, however, in the absence of Palingenia, Agrions and the larger dragon-flies were resorted to. A little vegetation had been taken with these (Ceratophyllum demersum and Lemna trisulca ten per cent.). probably by accident, as this lake was full of aquatic plants, and it would hardly have been possible for a fish to catch living food from the water without getting more or less regetation at the same time. A single Hymenopter-the only land insect 
found eaten by this species-was taken from this stomach. A specimen taken in June at Peoria had saten about equally of minute unrecognized fish-fry and Palingenia larvæ. One caught at Ottawa, in July, had eaten only insects-Corixa twenty-five per cent., Palingenia larvæ seventy-five per cent.

Table of Food of Pomoxys.

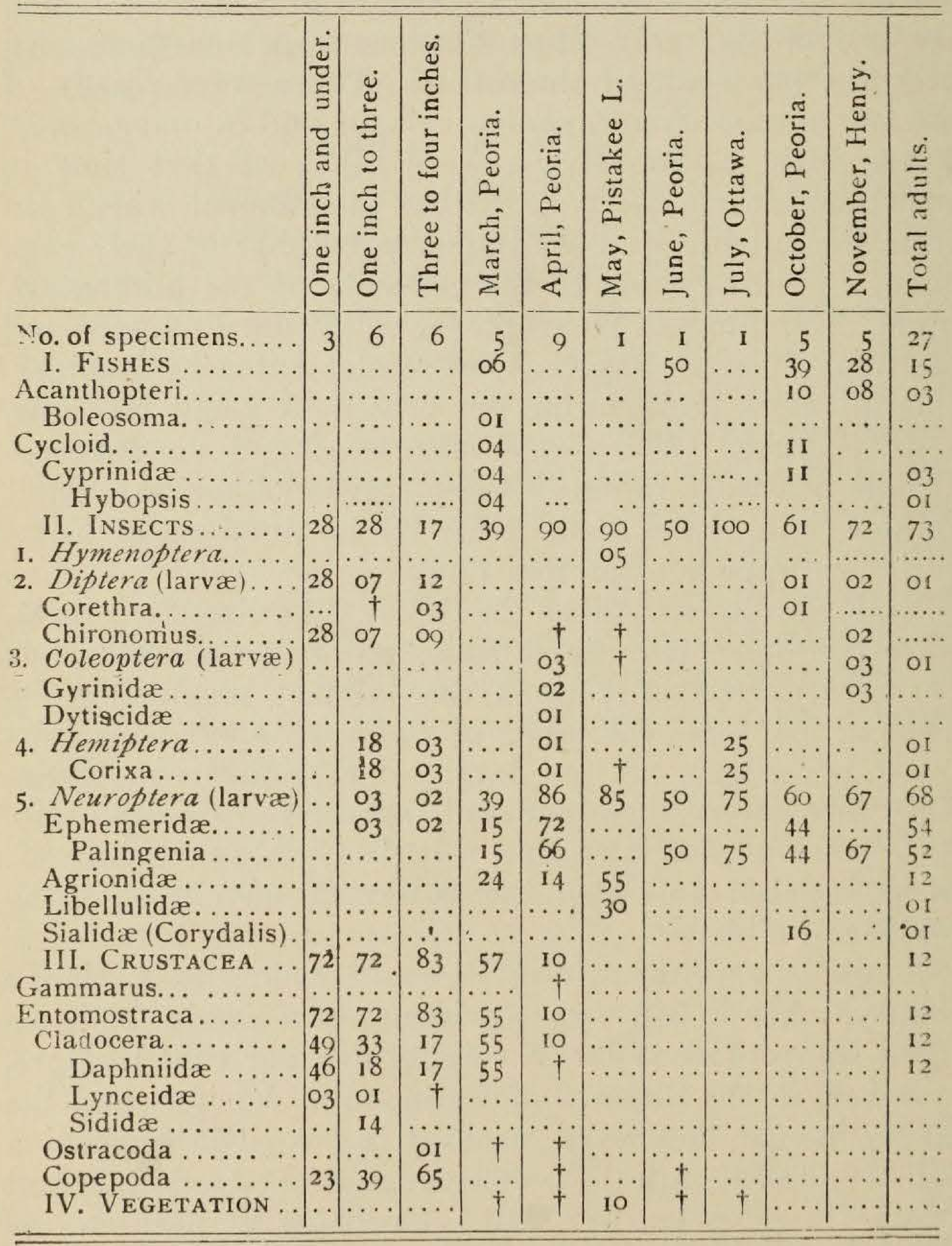

Five croppies from Peoria, in October, 1878, and five from Henry, thirty miles above, in November, 1877, indicate that the autumnal food of the species is again differ- 
ent. These had eaten, respectively, thirty-nine per cent. and twenty-eight per cent. of small fishes-partly $\mathrm{Cy}$ prinidæ and partly undetermined Acanthopteri. The remainder of their food was composed chiefly of Palingenia larvæ. One October specimen had eaten two larvæ of the large "helgramite", Corydalus cornutus. Although these fishes were taken directly from the seine, and opened upon the spot, the food in their stomachs did not average more than a fourth of the quantity in those taken in early spring. The weather during both these months was uncomfortably cold, with falling snow, and the food of these specimens probably gives a correct hint of the winter food of the species.

Fourteen of the above were Pomoxys nigromaculatus and twelve $P$. annularis-one not having been determined.

\section{Summary of the Family.}

For the purpose of a comparative recapitulation of the above data respecting the food of the sunfishes,. I have prepared three condensed tables, showing, upon the same page, the food of the different genera in parallel columns. The first table exhibits the food of the youngest specimens, the second, of those of intermediate size, and the third, of those which may properly be regarded as mature.

By an inspection of the first table, it will be seen that the thirty specimens, one inch long and under, representing eight genera, which appear thereon, have eaten little else than Entomostraca and larvæ of Chironomus-thesetwo elements amounting to ninety-three per cent. of the food. The only exception to this rule (that of the rock bass) is apparent rather than real. The large percentage of Neuropterous larvæ appearing under the name of that species is a technical ratio, inserted only for the sake of consistency, being based upon the fact that one of the specimens examined contained no food except a few traces of some indeterminable minute larvæ of that order. The minor differences in the food of the generic groups are doubtless due to differences of locality, and the like. That Ostracoda, for example, were found only 
in the stomachs of Centrarchus, is accounted for by the fact that the youngest specimens of this genus were taken from small mud-holes, favorable to the occurrence of Entomostraca of that order. The uniformity of food at this time implies that the selective apparatus of these fishes, whatever its construction, has not yet grown beyond the size of these minute animal forms.

From the second table of one hundred and six specimens we learn that with a general change of food from Entomostraca and Chironomus to larger Crustacea and insects, there appear certain differences-notably the continuance of Entomostraca as the most important element in Pomoxys, and the occurrence of mollusks in Eupomotis and of fishes in Micropterus. It is important to recall, at this point, that Pomoxys has the largest, finest and most numerous gill-rakers of the group-the best straining apparatus, in short-that Eupomotis has stout, blunt pharyngeal teeth, and that the black bass have relatively the widest mouths of all. It is also to be noted that the large-mouthed-bass commenced to take fish when an inch and a quarter long, and the small-mouthed species not until it reached a length of two and a half inches.

It will also be observed that Entomostraca are least abundant in the food of the small-mouthed black bass and the rock bass-species found usually in swift and shallow water, when of this size. The importance of water-bugs (Corixa) to the first three species of this table is evident.

From the table of adult food we find that these commencing peculiarities of the preceding table become here more prominent. All the Entomostraca of this table, except insignificant traces, now appear in the food of Pomoxys; the molluscan food of Eupomotis is nearly five times that of any other genus; and the ratios of fish food, running from eighty-six per cent. down to nothing, when arranged in a series, are seen to correspond, with curious exactness, to a series of the species themselves arranged according to the relative sizes of their mouths.

I was disappointed in being unable to find any food characteristics corresponding to such minor differences in the length of the gill-rakers of the anterior arch as ap- 
pear in Lepiopomus, Apomotis, etc., on the one hand, and Xenotis and Eupomotis on the other. If such peculiarities exist, they can probably be determined only by taking at one time and place a number of specimens of unlike character in this particular.

While I believe that the generalizations made above will hold good, at least for fishes of similar form and internal structure among the Acanthopteri, I do not wish to be understood as extending them at present beyond this order. Doubtless, while the characters mentioned must assist greatly in determining the food of a species $a$ priori, they are not by any means sufficient for this purpose when taken by themselves. The discussion of other features, external and internal, bearing upon this subject must be postponed to a later period of the investigation.

Tabie of Food of Young Centrarchide. (One inch and under.)

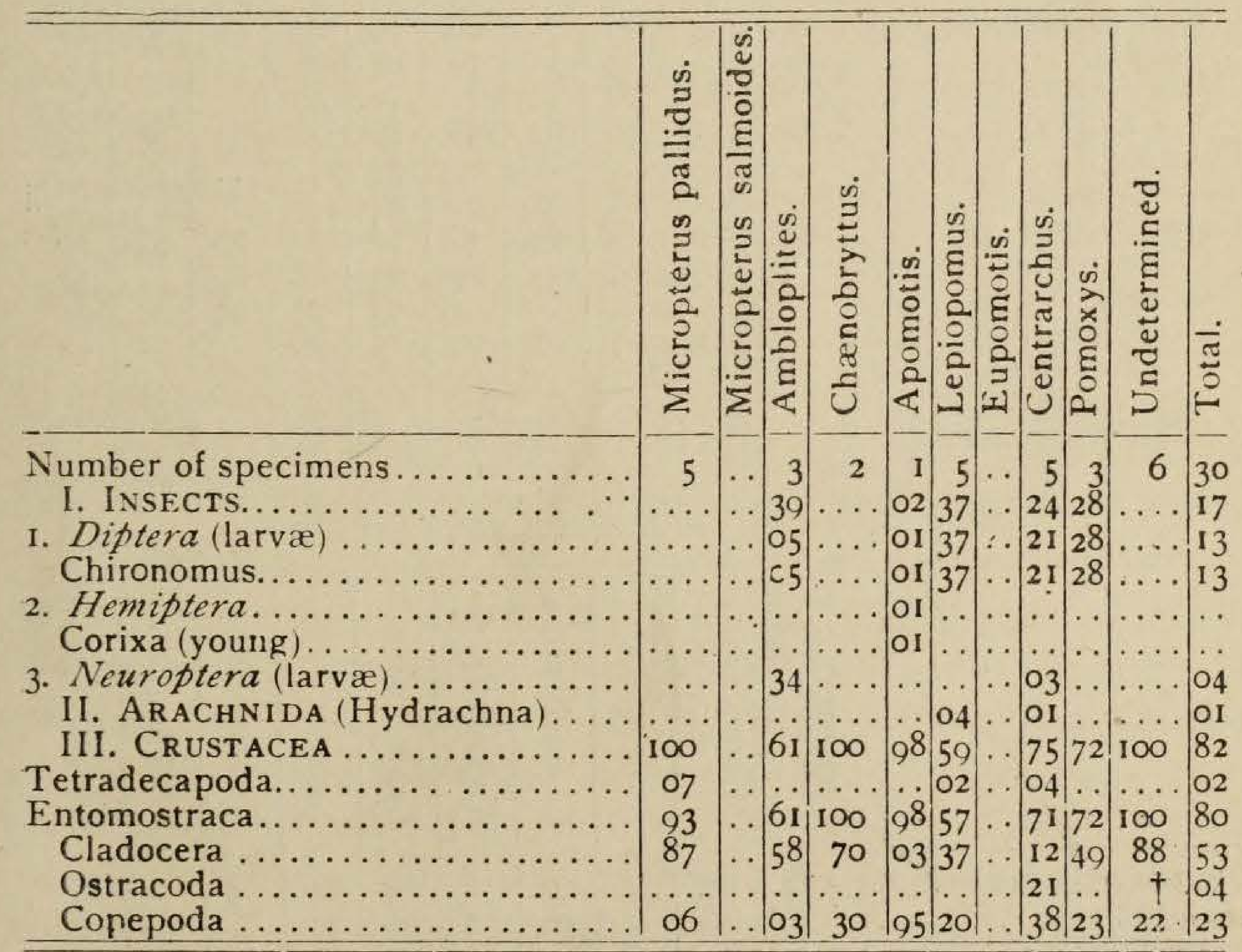


Table of Food of Young Centrarchide. (One to four inches.)

\begin{tabular}{|c|c|c|c|c|c|c|c|c|c|}
\hline$=$ & 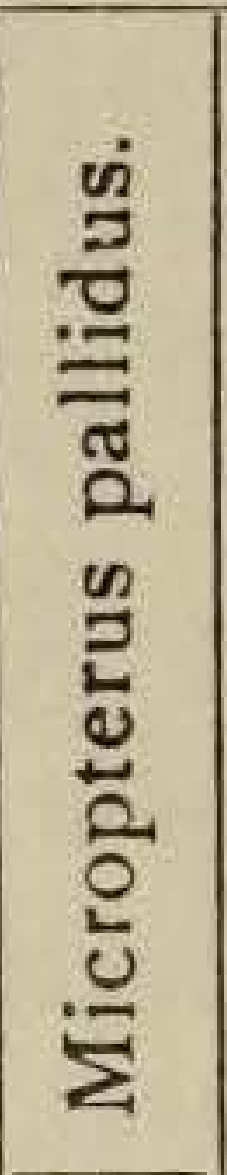 & 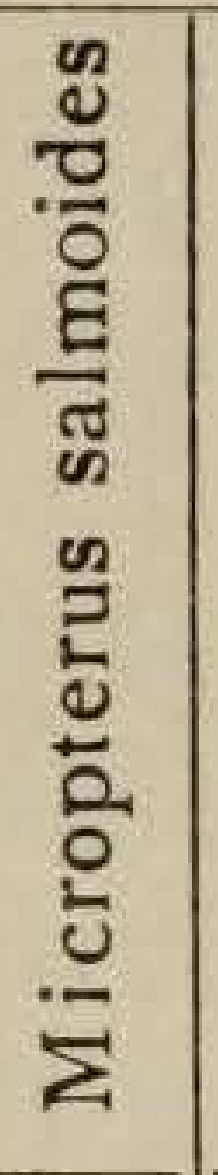 & 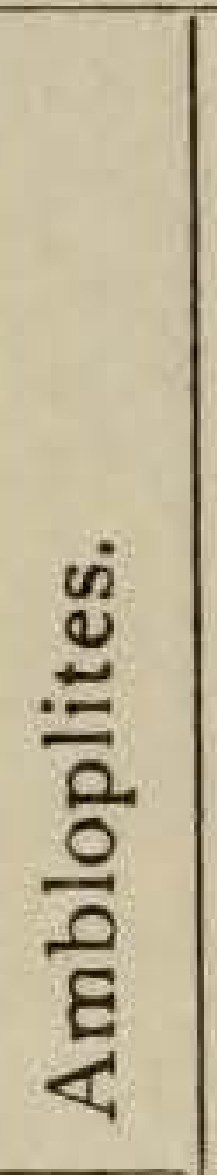 & 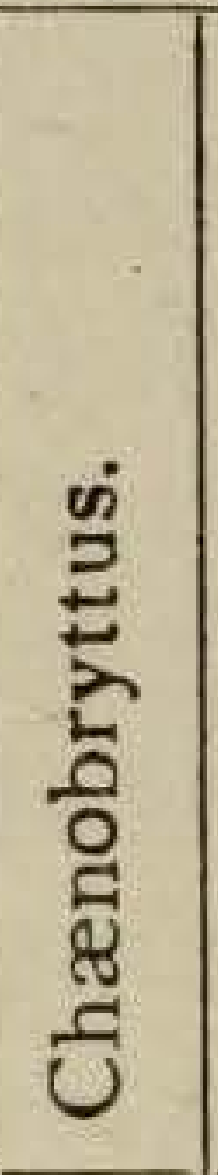 & 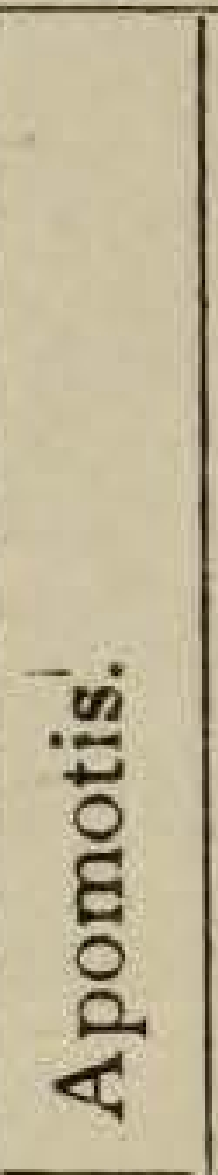 & 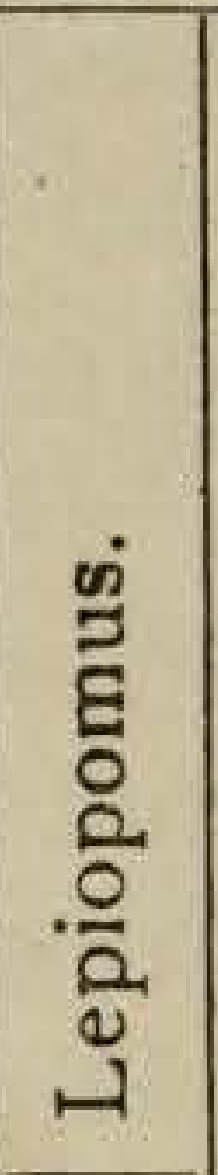 & 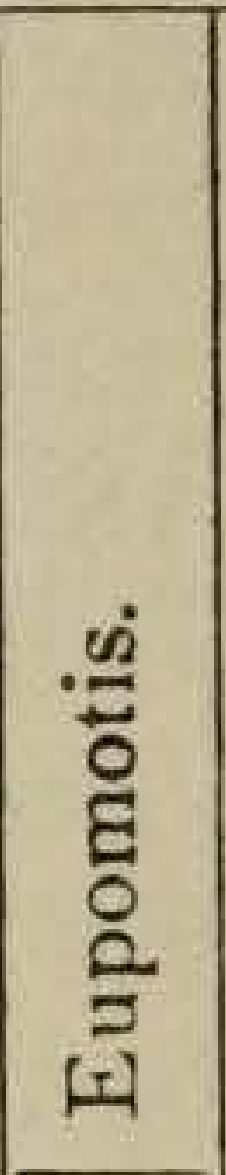 & 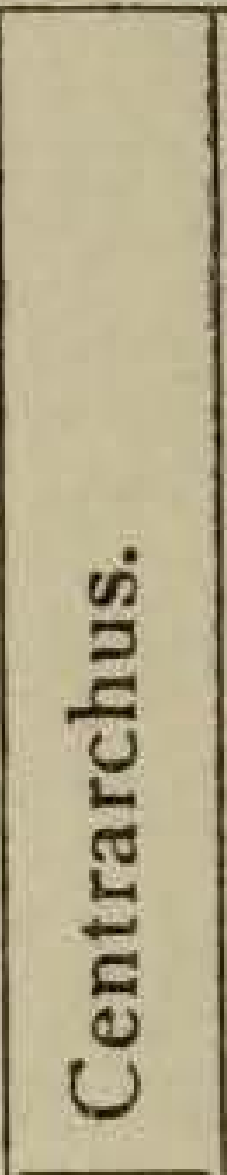 & $\begin{array}{l}\text { in } \\
\hat{x} \\
0 \\
\text { हू } \\
0 \\
0\end{array}$ \\
\hline pecimens........ & 12 & 24 & 5 & 8 & IO & 16 & I6 & 3 & 12 \\
\hline $\begin{array}{l}\text { I. FISHE } \\
\text { II. MOL }\end{array}$ & I5 & 06 & & $\cdots$ & $\cdots$ & & 08 & & \\
\hline III. Ins & 72 & 67 & 98 & 6I & 78 & 51 & 56 & 67 & 22 \\
\hline - Diptera (lar & OI & 03 & 02 & 18 & o9 & 28 & 44 & 04 & $\infty 9$ \\
\hline Chironom & or & OI & 02 & 15 & 07 & 28 & 43 & 04 & 08 \\
\hline 2. Coleoptera $\ldots \ldots \ldots \ldots \ldots$. & $\ldots$ & 02 & OI & & $\infty$ & $\dagger$ & OI & $\cdots$ & \\
\hline rial, & & & & & 07 & & & & \\
\hline Aquatic.............. & $x^{-1}$ & $\mathrm{O} 2$ & OI & & 02 & $\dagger$ & oI & & \\
\hline 3. Hemiptera (aquatic).... & 50 & 50 & 78 & 10 & 16 & II & .... & 23 & II \\
\hline & 49 & 50 & 76 & I0 & 16 & II & & 23 & II \\
\hline 4. Nen & 14 & 12 & .... & 33 & 33. & II & 10 & 37 & 02 \\
\hline emeridæ. . . . . . . . . . & 14 & 08 & & 08 & 29 & 05 & 08 & 37 & $\mathrm{O} 2$ \\
\hline & .... & 04 & .. & 19 & 04 & 06 & 02 & & \\
\hline & & & & & & 07 & & & \\
\hline , & 13 & 26 & $\mathrm{O} 2$ & 38 & 22 & 32 & 36 & 33 & 78 \\
\hline & & $\cdots$ & .... & ... & OI & .... & & & \\
\hline & ... & 23 & OI & & 04 & & 08 & & \\
\hline Ent & 13 & 03 & OI & 38 & 17 & 32 & 28 & 33 & 78 \\
\hline & 07 & $\mathrm{O} 3$ & .... & 29 & 09 & 08 & 08 & & 25 \\
\hline & & & $\cdots$ & & $\mathrm{O} 3$ & 03 & 20 & 12 & OI \\
\hline da............... & 06 & $t$ & OI & 09 & 05 & 20 & ... & 21 & 52 \\
\hline LYZOA . . . & & & $\cdots$ & & & 05 & & & \\
\hline & & $\cdots \cdot{ }_{2}>{ }_{3}$ & & & & 04 & & & \\
\hline VIII. VEgETATION . . . . . . & & oI & & OI & & OI & & & \\
\hline
\end{tabular}

Table of Food of Adult Centrarchide.

\begin{tabular}{|c|c|c|c|c|c|c|c|c|c|c|}
\hline * & 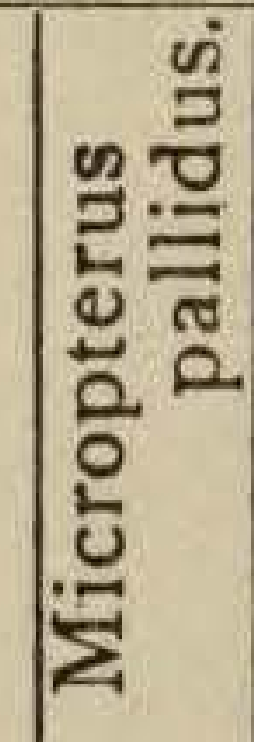 & 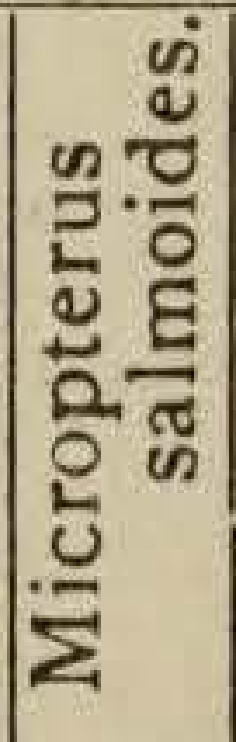 & 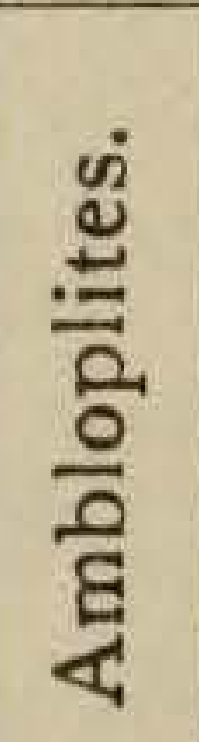 & 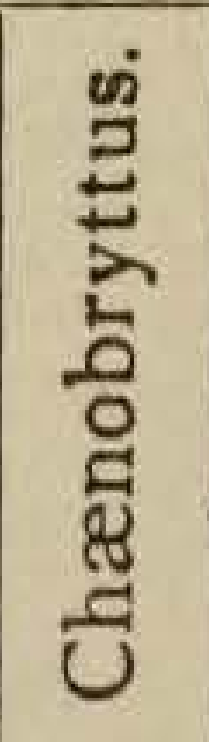 & 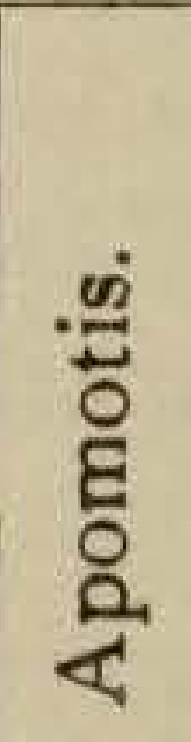 & 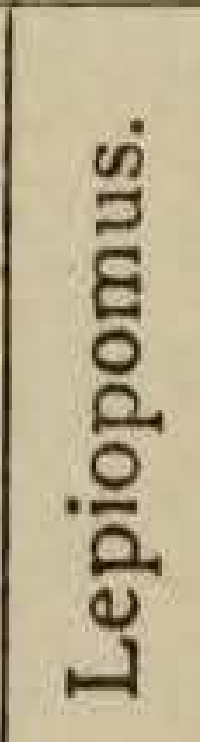 & 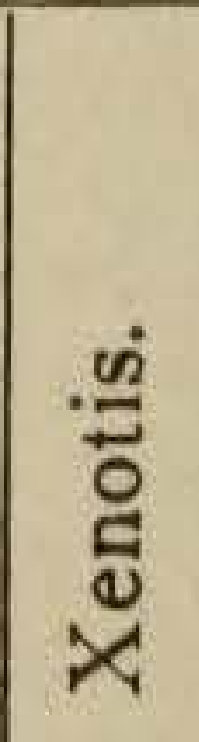 & 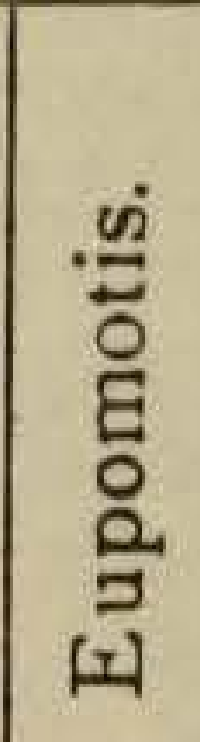 & & 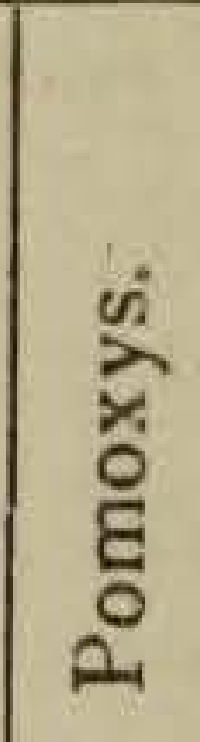 \\
\hline Number of specimens. & 14 & 3 & 4 & 6 & 8 & 24 & 6 & 9 & 2 & 27 \\
\hline I. FISHES $\ldots \ldots \ldots$ & 86 & 38 & I5 & 46 & 36 & OI & 07 & ... & .... & 15 \\
\hline Acanthopteri...... & 15 & & & $\cdots$ & $\cdots$ & OI & $\cdots$ & - $\cdots$ & … & 03 \\
\hline Dorysoma .... & 58 & & & & & $\cdots$ & & $\ldots$. & $\cdots \cdot$ & ... \\
\hline Cyprinidæ & 06 & & & ... & 12 & & & $\cdots$ & $\cdots \cdot$ & 03 \\
\hline $\begin{array}{l}\text { Silluridæ....... } \\
\text { II. MOLLUSC }\end{array}$ & 07 & & & & $\cdots$ & In & & & & $\cdots$ \\
\hline $\begin{array}{r}\text { II. Mollusca } \ldots \\
\text { Gasteropoda } \ldots \ldots\end{array}$ & & & & & & $\begin{array}{l}\text { IO } \\
\text { 10 }\end{array}$ & $\begin{array}{l}08 \\
04\end{array}$ & $\begin{array}{l}40 \\
33\end{array}$ & & $\cdots$ \\
\hline $\begin{array}{l}\text { Gasteropoda } \ldots \ldots \ldots \\
\text { Acephala } \ldots . . . . \ldots\end{array}$ & & & & & & + & $\begin{array}{l}04 \\
04\end{array}$ & $\begin{array}{l}33 \\
06\end{array}$ & & \\
\hline
\end{tabular}


Table of Food of Adult Centrarchid.e-Continued.

\begin{tabular}{|c|c|c|c|c|c|c|c|c|c|c|}
\hline & 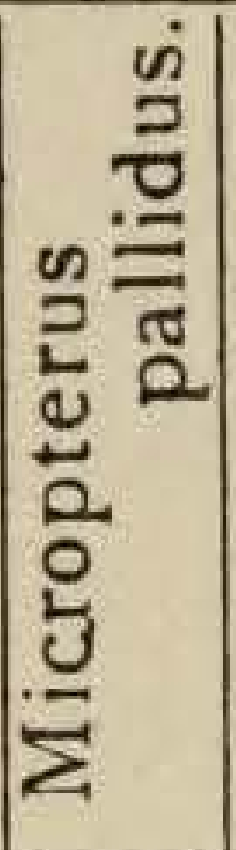 & 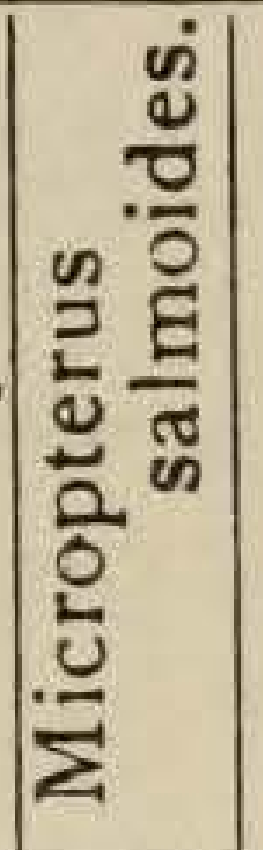 & 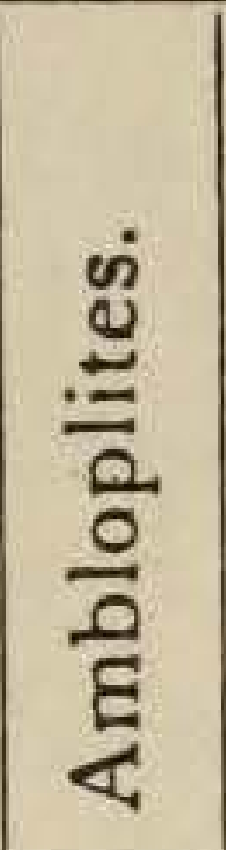 & 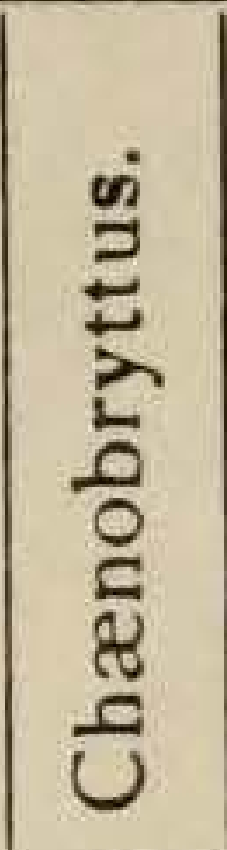 & 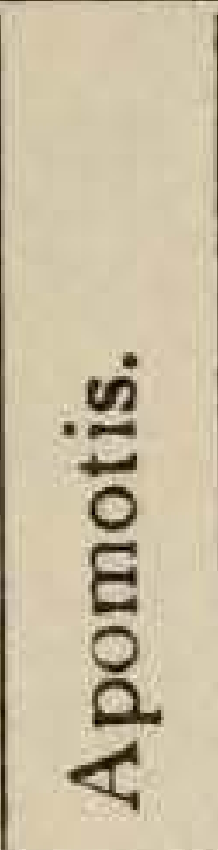 & 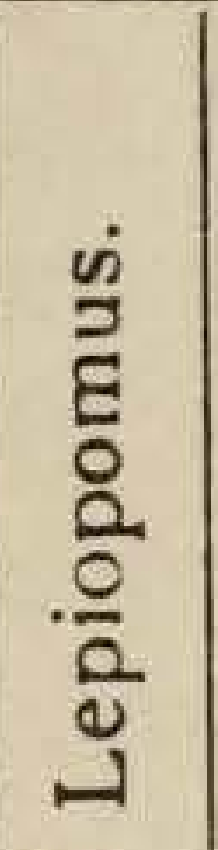 & $\frac{\dot{v}}{\frac{0}{0}}$ & 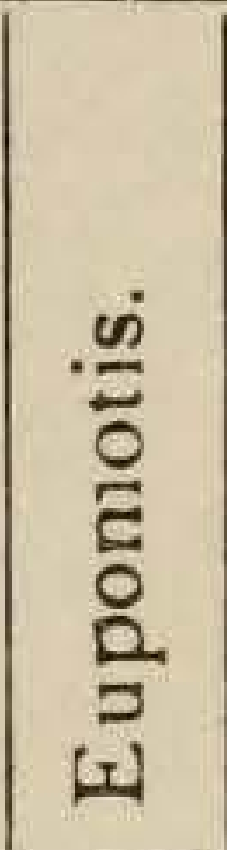 & 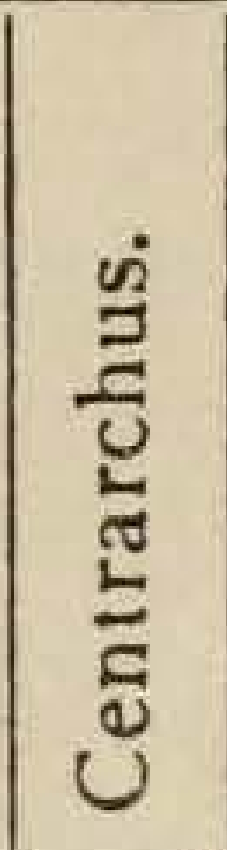 & $\begin{array}{l}\dot{v} \\
\grave{x} \\
\stackrel{0}{0} \\
\text { Ė } \\
0 \\
0\end{array}$ \\
\hline Number of specimens... & 14 & 3 & 4 & 6 & 8 & 24 & 6 & 9 & 2 & 27 \\
\hline III. InSECTA. . ...... & + & $\ldots$ & 52 & 54 & 42 & 45 & 82 & 20 & 9I & 73 \\
\hline I. Hymenoptera (ants).. & .... & $\ldots$ & & & $\ldots$ & & & & 07 & \\
\hline 2. Diptera (larvæe). & ... & ... & 06 & .. & ... & OI & 37 & OI & 06 & OI \\
\hline Chironomus...... & $\cdots$ & ... & $\ldots$ & & & .... & 37 & OI & 06 & \\
\hline 3. Coleoptera. ........... & $\cdots$ & $\cdots$ & 03 & Io & 05 & 13 & o5 & $\mathrm{O} 2$ & .... & OI \\
\hline $\begin{array}{l}\text { Terrestrial } \ldots \ldots \ldots \ldots \\
\text { Aginatic }\end{array}$ & $\cdots \cdot$ & . & $\ldots$ & IO & $\cdots$ & 06 & 04 & $\cdots$ & $\cdots \cdot$ & $\cdots$ \\
\hline 4quatic............... Hemiptera (Corixa). & $t$ & & $\mathrm{O} 3$ & $\ddot{8}$ & 05 & $\cdots$ & & $\mathrm{O} 2$ & & OI \\
\hline $\begin{array}{l}\text { 4. Hemiptera (Corixa).. } \\
\text { 5. Orthoptera ......... }\end{array}$ & & & & 18 & 03 & $\begin{array}{l}\mathrm{O} 2 \\
\mathrm{O} 2\end{array}$ & 17 & $\begin{array}{l}\cdots \\
\ldots\end{array}$ & 23 & \\
\hline $\begin{array}{l}\text { 5. Urthoptera.. } \\
\text { 6. Neuroptera.. }\end{array}$ & $\dagger$ & $\ldots$ & 42 & 25 & 33 & 24 & 16 & 17 & 35 & 68 \\
\hline Ephemeridæ. & . & & 21 & 25 & 27 & 03 & .... & 04 & 55 & 52 \\
\hline Palingenia. & . & . & & 25 & OI & $\mathrm{O} 2$ & & 03 & & 52 \\
\hline Odon & & & 06 & & 02 & 12 & & 08̈ & & 13 \\
\hline & & & $\ldots$ & & 04 & 06 & & .... & & OI \\
\hline Phryganeidæ... & $\cdots$ & & 15 & & $\cdots$ & $\mathrm{O} 3$ & 08 & OI. & & \\
\hline IV. ARACHNIDA & & & $t$ & & & & & $\cdots$ & & \\
\hline V. Crustacea & 07 & 62 & $3 \mathbf{I}$ & $t$ & 20 & I 8 & $\mathrm{O} 3$ & 22 & 09 & 12 \\
\hline Decapoda .......... & 07 & 62 & 31 & & 20 & OI & & ... & $\ldots$ & $\cdots$ \\
\hline Tetradecapoda... & $\cdots$ & $\cdots \cdots$ & $\cdots \cdot$ & $\cdots$ & $\cdots$ & 17 & 03 & 22 & & \\
\hline Entomostraca .... & & & $\cdots$ & & & t & $\cdots$ & $\ldots$ & 09 & 12 \\
\hline Cladoce & $\ldots$ & $\cdots \cdot$ & $\cdots$ & $\dagger$ & ... & t & & $\ldots$ & $\ldots$ & 12 \\
\hline Ostracgda...... & $\ldots$ & $\cdots \cdot$ & .... & $\cdots$ & & 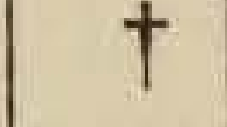 & & $\cdots$ & & \\
\hline Copepoda. ...... & $\therefore$. & & & & & & & & $\infty$ & \\
\hline $\begin{array}{l}\text { VI. Polyzoa............ } \\
\text { VII. Vegetation } \ldots\end{array}$ & + & $\ldots \ldots$ & 02 & . & $\ddot{02}$ & $\begin{array}{l}02 \\
24\end{array}$ & & 12 & & \\
\hline Miscellaneous... & 107 & & & & & & & & & \\
\hline
\end{tabular}

Haploidonotus grunniens, Raf. Sheepshead. Grunting Perch.

This species is abundant in Lake Michigan and the larger rivers, occurring in the smaller streams rarely, at periods of exceptionally high water. It is sometimes eaten, but is regarded usually as unfit for food.

But six of the twenty-five specimens studied were young, and the smallest of these, from the Ohio R., in September, was an inch and an eighth in length. Seventyfive per cent. of its food was larve of Chironomus and twenty-five per cent. larvæ of Palingenia bilineata. Besides the usual indications that the food of the very young. is made up of minute animals, we see here evidence that this species seeks its food from the first upon the bottom. 
In a specimen two inches long, the Chironomus larva fell to fifteen per cent., while the Palingenia larvæ rose to eighty per cent., and other Ephemerids and Cyclops made up the remainder of the food.

Four specimens, also from the Ohio, at Cairo, from two to four inches long, were found to have recently fed upon Ephemerid larvæ and larvæ of aquatic beetles, Gyrinidæ and Hydrophilidx, in about equal quantities. Only five per cent. of their food was Chironomus.

Sixteen individuals of medium size were taken from the Illinois and Ohio rivers, in April, June, September and October of four different years. There was nothing in the contents of these stomachs to indicate any difference in food resulting from these differences of date and situation. The food, on the contrary, was remarkably simple and uniform, consisting chiefly of the larva of Neuroptera (eighty-four per cent.), of which Palingenia bilineata formed altogether the most important part (seventy-six per cent.) - the remaining eight per cent. being dragon-flies. A single small sucker (Catostomidæ), a few mollusks (Planorbis, young Unios and thin-shelled Anodontas), and some Aselli complete the brief dietary of this group.

It is not until we examine the food of full-grown specimens that we wholly appreciate the utility of the enormous crushing pharyngeal jaws with their pavement teeth, found in this species. The entire food of the three large specimens examined, taken at Peoria, in April and October, proved to consist of mollusks only, including forty-six per cent. of the thick and heavy water snail, Melantho decisa, whose shell probably no other fish in our rivers could break. Cyclas, Anodonta and indeterminable Gasteropoda composed the remainder of the food. 